\title{
Uma Era de contradições: segregação e resistência afro-americana no período progressista, $1890-1920^{1}$
}

Carlos Alexandre da Silva Nascimento ${ }^{2}$

Resumo: O presente trabalho tem como objetivo uma análise acerca do processo de degradação das relações raciais entre brancos e negros nos Estados Unidos durante os anos de 1890 e 1920, bem como as formas de protesto empregadas pelos afro-americanos para combatê-la. Durante o período, historicamente denominado como Era Progressista, estruturou-se uma série de leis que se destinavam a privar os negros norte-americanos dos benefícios disponíveis àqueles considerados cidadãos estadunidenses. Além dessa legislação, conhecida como "Jim Crow", costumeiramente entendida como um fenômeno sulista, práticas informais de segregação e racismo também fizeram parte do norte e demais regiões do país. Convenções sociais procuravam demonstrar ao negro qual deveria ser sua posição na sociedade: se não mais a de um escravo, pelo menos a de um cidadão de segunda classe. Nessa configuração, apesar do nome e de alguns avanços sociais, a Era Progressista não foi tão progressista assim para os afro-americanos.

Palavras-chave: Era Progressista, segregação, afro-americanos.

\section{An Era of contradictions: segregation and African-American resistance at progressive period, $1890-1920$}

\begin{abstract}
The present paper aims at analyzing the process of the degradation of race relations between whites and blacks in the United States during the 1890s and 1920s and the forms of protest used by African Americans to fight it. During the period, historically called the Progressive Era, a series of laws was enacted to deprive black Americans of the benefits available to those considered American citizens. In addition to this legislation known as "Jim Crow," understood as a Southern phenomenon, informal practices of segregation and racism were also part of the north and other regions of the country. Social conventions sought to demonstrate to blacks what their position in society should be: if not more than that of a slave, at least that of a second-class citizen. In this configuration, despite the name and some social advances, the Progressive Era was not so progressive for African-Americans.
\end{abstract}

Keywords: Progressive Era, segregation, African-Americans.

${ }^{1}$ Gostaria de agradecer o Prof. Dr. Robert Sean Purdy, do Departamento de História da Universidade de São Paulo - USP, pelas contribuições para o desenvolvimento desse artigo.

2 Doutorando em História Social pela Universidade de São Paulo. Pesquisa em andamento: Cartas ao editor: discutindo o universo racial norte-americano em The Crisis Magazine, 1910-1934. Orientado pelo Prof. Dr. Robert Sean Purdy. Órgão financiador: CNPq. E-mail: alexandre1@usp.br.

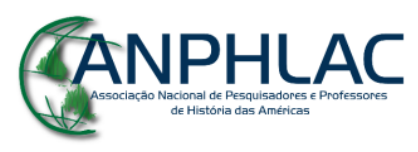

Revista Eletrônica da ANPHLAC, ISSN 1679-1061, № 27, p. 103-143, Ago./, Dez., 2019.

http://revista.anphlac.org.br 
Artigo recebido em: 17/03/2019

Artigo aprovado para publicação em: 28/10/2019

\section{Era Progressista: um contexto}

A história da humanidade está convencionalmente dividida em eras. Cada uma delas tem por objetivo destacar mudanças que, de alguma forma, a maior parte das sociedades, ou pelo menos aquelas com as quais mais temos contato, passa a se estruturar para sofrer menos os impactos de alterações às quais são submetidas. No que se refere ao continente americano, nenhum outro país parece ser tão disposto a empregá-las quanto os Estados Unidos.

Sendo criações artificiais de historiadores, porém, raramente é possível definir a linha que separa uma era da outra, sendo, de acordo Upchurch (2009, p. xxvi), meramente traçadas com o propósito de "empacotar informações em pequenas caixas organizadas". Nos Estados Unidos, esse fascínio por se entender empregando a divisão por eras remonta a explicações historiográficas da era colonial. Contudo, poucos períodos da história do país parecem ser mais intensos e paradoxais quanto a Era Progressista. ${ }^{3}$

Procurando corrigir os excessos e a corrupção do período anterior, a Gilded Age (Era Dourada), indivíduos e instituições se lançaram em uma cruzada para reformar a sociedade e o Estado norte-americano da modernidade que, na sua visão, ameaçava o estilo de vida e os sonhos de seus habitantes. Vista muitas vezes com datações variadas, a periodização empregada por Nichols e Unger (2017, p. 17), embora entendam a Era Dourada e a Era Progressista como um longo período devido às suas interações, especifica que de 1890 a 1920, a intenção dos progressistas, em sua maioria membros da classe média que se viram aterrorizados por um lado pela pobreza e por outro pelo grande capital, era utilizar o governo para reformar o país e expandir seus valores pelo mundo.

Durante aqueles anos, movimentos sociais reformistas como o settlement house, que buscava o compartilhamento de experiências e trocas de conhecimento entre ricos e pobres, no intuito de diminuir as disparidades entre as classes sociais, eram vistos como

${ }^{3}$ Para saber mais sobre os aspectos gerais do período, ver: ANDERSON, William G. Progressivism: An Historiographical Essay. In: The History Teacher, v. 6, n. 3, May 1973, p. 427-452 e RODGERS, Daniel T. In Search of Progressivism. In: Reviews of American History, v. 10, n. 4, Dec. 1982, p. 113-132.

\section{GANPHLAC}

Revista Eletrônica da ANPHLAC, ISSN 1679-1061, № 27, p. 103-143, Ago./, Dez., 2019.

http://revista.anphlac.org.br 
alternativas para a melhoria das condições de vida dos mais necessitados. Atenção também foi dada ao papel feminino na sociedade desviando o foco daquelas concepções que necessariamente conectavam a mulher aos afazeres domésticos, revelando pensadoras que se destacaram no campo científico. ${ }^{4}$ No universo trabalhista, trabalhadores urbanos e rurais militaram por maior reconhecimento de suas necessidades, viram na voracidade capitalista a origem de suas mazelas e se organizaram para ampliação de seu poder de barganha e direitos. Contudo, enquanto grande parte da sociedade buscava melhores oportunidades de vida para os cidadãos estadunidenses, presenciava-se um processo de segregação racial que tinha no afro-americano o seu principal alvo.

A exclusão era a percepção mais comum que o negro sentia em relação à sociedade na qual estava inserido. Práticas de violência física e moral, degradação econômica, vítimas de um sistema de justiça tendencioso, eram algumas das situações que os negros precisavam enfrentar. É nesse contexto de reformulação e reafirmação de valores que se instaura um conjunto de artifícios legais que procurou limitar o progresso e as aspirações do grupo afro-americano. Conhecidas como Leis Jim Crow, essa complexa rede de segregação tinha por fundamentação preceitos raciais que vigoraram de meados de 1880 até a segunda metade de 1960. Embora seja mais relacionada à segregação de afro-americanos, outros elementos da população, como nativo-americanos e latino-americanos, também foram vítimas de suas práticas. Ainda que esse fenômeno existisse por todo o país, esteve mais relacionado às práticas discriminatórias e excludentes que vigoravam na região sul, onde se concentrava a maior parcela da população negra, abrangendo aproximadamente 90 por cento do total. ${ }^{5}$

Embora o termo progressista possa fazer crer que tudo que foi feito estava destinado à plena satisfação do cidadão norte-americano comum frente às ameaças do grande capital que prometia engoli-lo, certa dose de cautela deve ser empregada quando

\footnotetext{
${ }^{4}$ Exemplo disso pode ser visto no livro de Rosalind Rosenberg, no qual a autora procura demonstrar as conexões entre o universo intelectual norte-americano que procurava impedir o destaque de mulheres e o desenvolvimento do feminismo no início do século XX. Cf. ROSENBERG, Rosalind. Beyond separate spheres: intellectual roots of modern feminism. New Haven, CT: Yale University Press, 1982.

${ }^{5}$ Cf. MALONEY, Thomas N. African Americans in the Twentieth Century. In: E.H.Net Encyclopedia. edited by Robert Whaples. January 14, 2002.
}

\section{CANPHLAC}

Revista Eletrônica da ANPHLAC, ISSN 1679-1061, № 27, p. 103-143, Ago./, Dez., 2019. http://revista.anphlac.org.br 
nos referimos ao período. Em observação ao campo historiográfico, as análises que procuraram questionar o quão progressista o movimento era mereceram atenção mais apurada. Segundo Diner (1998, p. 13), nem tudo que foi realizado tendo como preceito a ideia de reforma dominou todos os aspectos da vida estadunidense ou pode ser visto como algo positivo. Em seu entendimento, os anos compreendidos entre 1890 e a Primeira Guerra Mundial são repletos de exemplos que descaracterizariam o que se possa entender como progressista. Tais exemplos podem ser vistos como a tendência à repressão violenta a grevistas, a constante pauperização das condições de vida dos trabalhadores urbanos e rurais, ao acentuado fenômeno de linchamento de afro-americanos e a efetivação do processo de segregação imposta pelos sulistas brancos que privaram de direitos os negros da região. Para o autor, estes e muitos outros aspectos do período não são progressistas por qualquer definição moderna (DINER, 1998, p. 13).

Ainda que interpretações destaquem a predisposição dos reformadores progressistas em resolver certas disparidades entre os diversos grupos sociais, no que se trata ao afro-americano o empreendimento pareceu uma tarefa ainda mais peculiar. Regidos por concepções racistas que acreditavam ranquear as sociedades e grupos humanos, diversos progressistas também foram levados a aceitar a concepção de que tal divisão era um elemento que compunha o seu país. De acordo com McGerr (2005, p. 183), existiam certos limites na crença dos progressistas em transformar as pessoas, pois a segregação revelou um senso de realismo e sublinhou certo pessimismo na classe média. Nesse aspecto, mesmo empenhados em resolver as diferenças de classe, sentiram que algumas destas não poderiam ser resolvidas, restando então preservar os grupos mais fracos e vulneráveis da aniquilação (McGERR, 2005, p. 183). De igual maneira, Southern $(2005$, p. 2) argumenta que políticos e pensadores da época se tornaram influenciados por aquela forma de pensamento, pois a ciência daquele tempo dizia aos progressistas que o afro-americano era inatamente inferior e deveria permanecer na base da escala social. Em seu entendimento, até mesmo aqueles brancos que acreditavam e advogavam pelos direitos dos negros se frustravam com a impressionante oposição no que se refere à igualdade racial (SOUTHERN, 2005, p. 2).

\section{CANPHLAC}

Revista Eletrônica da ANPHLAC, ISSN 1679-1061, № 27, p. 103-143, Ago./, Dez., 2019. http://revista.anphlac.org.br 
A complexidade atribuída à Era Progressista, no que se trata às relações sociais, encontra no convívio entre brancos e negros o seu exemplo mais contundente. Se por um lado, os diversos grupos em conflito procuraram formas de solucionar suas demandas, muitas vezes se aliando a outros grupos que apresentavam necessidades semelhantes, por outro pregavam prudência no tocante a uma convivência mais íntima. ${ }^{6}$ Nesse aspecto, torna-se evidente que o fator racial era um dos aspectos mais determinantes para o sucesso ou fracasso das relações entre as duas parcelas da população.

Mesmo nesse cenário desanimador, alianças mais sérias e duradoras fizeram parte do ambiente progressista que tomou conta dos Estados Unidos do final do século XIX às duas primeiras décadas do século XX. Procurando agir dentro do sistema democrático, progressistas brancos e negros viram na sua união o amplo horizonte que se apresentava diante deles e por meio da exposição dos absurdos decorrentes da exclusão dos negros estadunidenses, fizeram com que grande parte da sociedade, que se vangloriava de seus preceitos democráticos, repensassem o tratamento a eles dispensado.

\section{Um “ensaio" com os Black Codes (1865-1867)}

A Guerra Civil Americana, 1861-1865, pode ser considerada o evento mais dramático da história do país. Precipitado pela primeira eleição de Abraham Lincoln, em 1860, o fato apresenta uma variedade considerável de elementos como possíveis causas, desde percepções que a relacionam à intenção do presidente em principalmente preservar a União até o questionamento sobre a instituição escravista como obstáculo ao pleno desenvolvimento do capitalismo. De acordo com Eric Foner (1980, p. 19), o conflito deu destaque a questões decisivas sobre a experiência nacional, tais como o relacionamento entre os estados e o governo federal, o equilíbrio entre força e consentimento no sentido de obediência à autoridade e o problema envolvendo raça que ainda perturba o país.

\footnotetext{
${ }^{6}$ Como exemplo, podem ser citadas as Farmer's Alliances (Alianças de Fazendeiros), que dando origem ao Partido Populista, pregavam uma aproximação entre trabalhadores rurais negros e brancos que sofriam com pauperização de suas condições de vida e que nas eleições em que disputou, contou com considerável aderência dos afro-americanos. Para saber mais, ver: BREXEL, Bernadette. The Populist Party: a voice for the farmers in an industrial society. New York: Rosen Publishing Group, 2004.
}

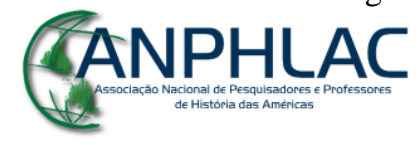

Revista Eletrônica da ANPHLAC, ISSN 1679-1061, № 27, p. 103-143, Ago./, Dez., 2019. http://revista.anphlac.org.br 
O período conhecido como Reconstrução, ou Era da Reconstrução, que na maioria das interpretações abrange os anos de 1865-1877, foi o período durante o qual a sociedade norte-americana procurou se adequar ao novo estado de coisas deixado pela Guerra Civil. O historiador Eric Foner, por exemplo, adota o ano de 1863 para salientar a importância da Proclamação de Emancipação. ${ }^{7}$ Nesse momento conturbado da história do país, as forças da União ocuparam a região sul e o governo federal empreendeu medidas para que a nova situação dos negros, agora libertos, fosse reconhecida pelos antigos rebeldes. Durante aqueles anos, três emendas constitucionais foram acrescentadas. A Décima Terceira Emenda, de 1865, dizia respeito à efetiva abolição da escravidão promulgada em janeiro de 1863 com a Declaração de Emancipação. A Décima Quarta, de 1868, trata da garantia de direito à cidadania de todas as pessoas nascidas ou naturalizadas no país e a legítima proteção destas de acordo com a lei. A Décima Quinta, de 1870, garantia o direito ao sufrágio de todos os cidadãos norte-americanos sendo proibido ao governo federal e aos estados negar-lhes em razão de raça, cor ou situação anterior a servidão.

A historiografia da Reconstrução apresenta desde o início do século XX uma ampla gama de interpretações. Inicialmente, o período foi visto como desastroso não apenas para o sul, mas para todo o país. O precursor dessa forma de análise foi William A. Dunning, que publicou em 1907 o livro Reconstruction, Political and Economic 18651877. Um dos primeiros a desafiar tal viés de interpretação foi o afro-americano William Edward Burghardt Du Bois, em 1935, com Black Reconstruction in America, 1860-1880. Para o autor, verdadeiros esforços foram realizados para se implantar no sul preceitos democráticos e uma política de boa convivência entre brancos e negros. Embora significativo, o livro não obteve o reconhecimento que mereceu devido ao forte fator racial que vigorava na sociedade do país. A partir da década de 1960, o revisionismo histórico sobre a Reconstrução contribuiu para mitigar o impacto que as interpretações que seguiam a Escola de Dunning tinham estabelecido. Dentre os pontos que foram abordados está o esforço para reerguer a economia sulista, a garantia de direitos para os

\footnotetext{
${ }^{7}$ Ver: FONER, Eric. Reconstruction: America's Unfinished Revolution, 1863-1877. New York: Harper \& Row, 1988a.

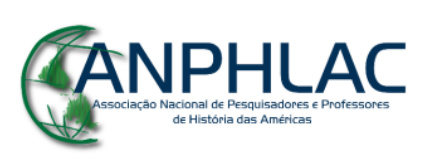


negros e o estabelecimento de um sistema público de ensino, já mencionado por Du Bois no livro citado acima.

Antes que a segregação imposta pelas leis Jim Crow se tornasse uma realidade e algo quase que natural no contexto vivido pelos afro-americanos, destacadamente no sul do país, outras medidas, no imediato pós-guerra civil, procuraram apresentar aos negros como tais seriam tratados assim que as hostilidades entre a União e os confederados fossem gradativamente esquecidas. ${ }^{8}$

Entendendo sua situação no conflito e a iminência da emancipação de seus escravos, os senhores de terras da região, juntamente aos seus aliados políticos, procederam a diversificadas manobras para restringir ao máximo possível os ganhos adquiridos pelos então "homens livres". Segundo Cuthbert-Kerr (2008), os Black Codes (Códigos Negros), estipulados entre os anos de 1865-1866, tinham como determinante restringir as atividades do povo negro principalmente no que se referia às relações de trabalho. Sendo a economia dos estados sulistas estruturada no esquema agrário, as previsões dos senhores da região seriam de completa ruína assim que os negros tivessem capacidade para arquitetar formas mais favoráveis de negociações trabalhistas.

O renomado historiador Eric Foner (1988b) destaca o desenvolvimento das questões envolvendo o caráter do trabalho no período pós-Emancipação tendo como base as regiões produtoras de arroz da Carolina do Sul. Como demonstrado por Foner (1988b, p. 135-136), pouco após o fím da Guerra Civil, muitos dos libertos passaram a entender liberdade e propriedade como rigidamente imbricadas e fizeram o possível para garantir o direito a ambas. Em atitudes consideradas ousadas desafiaram seus antigos senhores quando estes exigiam que saíssem de suas propriedades. Em outras situações, apenas restava aos fazendeiros da região negociar com os homens negros caso quisessem retornar aos negócios. Dentre as formas de acordo estabelecidas, estão o aluguel das plantações por uma parte da colheita e o sistema de "dois dias", a partir do qual o trabalhador deveria

${ }^{8}$ Os Estados Confederados da América ou A Confederação foi uma união política entre onze estados que se separaram dos Estados Unidos da América entre os anos de 1860-1861 por decorrência da primeira eleição de Abraham Lincoln que, segundo eles, apresentava uma posição hostil ao escravismo. Os estados eram: Carolina do Sul, Mississippi, Flórida, Alabama, Geórgia, Louisiana, Texas, Virgínia, Arkansas, Carolina do Norte e Tennessee.

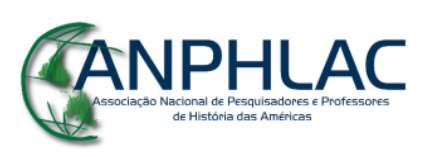

Revista Eletrônica da ANPHLAC, ISSN 1679-1061, № 27, p. 103-143, Ago./, Dez., 2019. http://revista.anphlac.org.br 
dedicar dois dias de trabalho na fazenda em troca de um lote de terra onde poderia produzir seus próprios produtos.

A relativa autonomia negra na relação de trabalho nessa região do sul estadunidense não impediu que greves ocorressem. Próximo ao fim do período de Reconstrução, em 1876, os trabalhadores diaristas entraram em greve por salários pagos em dinheiro bem como o seu aumento. Segundo Foner (1988b, p. 152-154), atos de violência contra outros trabalhadores diaristas que não aderiram à greve foram registrados e os fazendeiros tiveram de ceder às exigências dos grevistas. A atuação do governador do estado na época, Daniel H. Chamberlain, do Partido Republicano, foi vista como um ato de interesse político, o que contribuiria para o fortalecimento do Partido Democrata. Diversas outras greves ocorreram no período.

Outro importante estudioso que se debruçou sobre as consequências da Era da Reconstrução foi o afro-americano W. E. B. Du Bois. Em uma obra magistral de caráter marxista intitulada Black Reconstruction in America, publicada em 1935, Du Bois estabelece um revisionismo histórico e bibliográfico que caracterizava o período como essencialmente desastroso para a história norte-americana. Analisando diversos aspectos do período, aponta que certos benefícios, como o estabelecimento de um sistema público de educação, foram levados ao sul de forma a contribuírem para o engrandecimento de negros e brancos. Com relação às questões envolvendo o mundo do trabalho, Du Bois (1995, p. 680) afirma que o uso do elemento racial foi utilizado pelos proprietários do sul para induzir o branco pobre a aceitar a sua condição em vez de estabelecer uma união com os trabalhadores negros. Dessa forma, "um movimento trabalhista no sul tornou-se impossível.

De acordo com Packard (2011, p. 41), outros determinantes para que o conjunto de leis que caracteriza esse período fosse implementado pelos sulistas, ainda que derrotados no conflito, foram: a visão de que os legisladores do norte não tinham um plano prático sobre como gerenciar a questão dos recém-libertos, a perspectiva de que não seriam indenizados pelos escravos perdidos, o interesse dos abolicionistas sobre as necessidades dos negros seria destruída assim que o objetivo de eliminar a escravidão fosse alcançado. Podem ser acrescentados a tais prognósticos as prévias propostas dos presidentes

\section{GANPHLAC}

Revista Eletrônica da ANPHLAC, ISSN 1679-1061, № 27, p. 103-143, Ago./, Dez., 2019.

http://revista.anphlac.org.br 
Abraham Lincoln, em sua Proclamação de Anistia e Perdão, de 1863, e de seu sucessor Andrew Johnson, em 1865, que não determinavam procedimentos mais rígidos para que os estados em rebelião fossem reintegrados ao governo federal. ${ }^{9}$

Com esse cenário relativamente livre para agir e com novas legislaturas estaduais alinhadas à proposta de anistia do presidente Johnson, os estados do sul começaram a apresentar suas "recomendações" para o futuro relacionamento entre brancos e negros. $\mathrm{O}$ primeiro desses estados foi o Mississippi, em 1865. Como uma maneira de manter a força de trabalho do negro submissa aos fazendeiros, leis de vadiagem foram endurecidas. De acordo com Smith (2006, p. 73), a definição de "vadios" foi ampliada para incluir negros e brancos ociosos que se associavam a eles "em termos de igualdade" ou com quem fosse demonstrado que tivessem tido relações sexuais. Ainda segundo o autor, tanto negros quanto brancos recebiam multas, mas estes últimos poderiam burlá-las por meio de um atestado de pobreza, enquanto que os negros que não pagassem após cinco dias seriam "arrendados" por meio de leilões para custear as multas e os gastos com as cortes. Segundo McCaslin (2010, p. 651), além dessa destacada vigilância, os negros do estado poderiam possuir terras unicamente nas cidades, eram limitados em sua capacidade de testemunhar em processos judiciais e sofriam punições caso deixassem os empregos. Restrições quanto à liberdade de culto, circulação em determinadas horas do dia ou ao porte de armas ou munições eram comuns em vários estados da região.

Não tendo a posse dos meios de produção ou encontrando sérios obstáculos para sua aquisição, restava ao negro norte-americano, recém-saído da escravidão, sujeitar-se a contratos de trabalho muitas vezes impostos pelos seus ex-senhores e legitimados pelos governos estaduais. Como salientado por Smith (2006, p. 73), no Texas, o empregado podia até escolher o seu empregador, mas uma vez que isso fosse determinado deveria

\footnotetext{
${ }^{9}$ As propostas definidas por Lincoln, ainda durante o conflito, tinham por objetivo atrair a maior quantidade de estados confederados possível. Dentre os pontos, estabelecia que se 10 por cento dos eleitores daqueles estados fizessem um voto de lealdade à União, seriam readmitidos. As ofertas apresentadas por Andrew Johnson eram ainda mais convidativas, não exigindo, por exemplo, uma porcentagem para aquela condição, bastando apenas o desejo dos insurgentes em apoiar a Constituição e a União. Cf. TREFOUSSSE, Hans L. Amnesty Proclamations. In: ZUCZEK, Richard (ed.). Encyclopedia of the Reconstruction era. Westport, Connecticut; London: Greenwood Press, 2006, v.1, p. 43-47.
}

\section{GANPHLAC}


completar todo o período estipulado no contrato, caso o motivo da quebra deste não fosse imposto pelo empregador.

Em meio àquele estado de coisas, os negros da região procuraram formas de eliminar os Códigos Negros e buscar maiores esclarecimentos sobre sua real condição de homens livres. De acordo com Kuthbert-Kerr (2008, p. 83), petições em estados como o Mississippi e Carolina do Sul solicitaram que os respectivos governadores assegurassem ao restante da população que não havia nenhum desejo daquela camada da população em se sublevar contra seus antigos senhores. Além disso, demandaram imediatamente igualdade de tratamento.

As determinações empreendidas pela legislação dos Códigos Negros despertaram irritações tanto na população quanto nos governantes do norte do país. Para muitos, a intenção dos sulistas em manter os mesmos laços que ligavam escravos e senhores fazia com que as perdas materiais e humanas provenientes da Guerra Civil fossem percebidas como algo em vão. Discordâncias entre o presidente Andrew Johnson e o Congresso, composto por alguns Republicanos considerados radicais, tais como Charles Sumner e Thaddeus Stevens, proporcionaram o desmantelamento de tais leis, embora com duras penas. ${ }^{10}$ Dentre os instrumentos utilizados para afirmar a derrota sulista e o processo de reconstrução do país estão a criação do Bureau of Refugees, Freedmen, and Abandoned Lands (Serviço de Refugiados, Libertos e Terras Abandonadas) ${ }^{11}$, em 1865, o Civil Rights Act (Lei dos Direitos Civis) ${ }^{12}$, em 1866, e o Military Reconstruction Acts (Leis Militares

\footnotetext{
${ }^{10}$ Ala do Partido Republicano que procurava empreender punições mais rigorosas aos estados, até então, em rebelião. Significativas medidas impostas no imediato pós-guerra civil contaram com o apoio dessa parcela do partido que, devido a desentendimentos com presidente Johnson, propôs sem êxito o seu impeachment em 1868. A morte de seus principais representantes até a primeira metade da década de 1870 enfraqueceu substancialmente a sua existência. Ver: DEHLER, Gregory J. Radical Republicans. In: ALEXANDER, Leslie M.; RUCKER, Walter C. (eds.). Encyclopedia of African-American history. Santa Barbara, California: ABC-CLIO, 2010, p. 974-976.

${ }^{11}$ Mais conhecido como Freedmen's Bureau, tinha a função de proporcionar a transição dos negros da escravidão para a condição de homens livres. Desde o início, essa agência do governo federal contou com fortes obstáculos tais como a falta de recursos e a resistência dos brancos sulistas que a consideravam um elemento a impor condições de igualdade entre brancos e negros. Apesar disso, proporcionou o primeiro contato de milhares de afro-americano com a educação. A agência foi desmantelada em 1872. Para saber mais, ver: CIMBALA, Paul A. The Freedmen's Bureau: reconstructing the American South after the Civil War. Malabar, FL: Krieger Publishing, 2005.

${ }^{12}$ Medida que entrou em vigor em abril de 1866 com a finalidade de estabelecer maior proteção aos antigos escravos efetivando a Décima Terceira Emenda e tentando mitigar os efeitos dos Black Codes. Apesar de
}

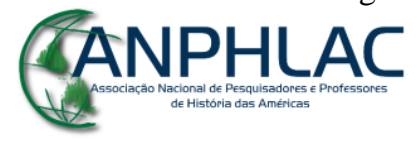

Revista Eletrônica da ANPHLAC, ISSN 1679-1061, № 27, p. 103-143, Ago./, Dez., 2019. http://revista.anphlac.org.br 
de Reconstrução) ${ }^{13}$, de 1867 e 1868. Se levarmos em conta a relutância dos estados que formaram a Confederação em aceitar não apenas as disposições da rendição, mas também a forma como as relações entre negros e brancos seriam definidas, a Décima Quarta Emenda deve ser entendida como mais um elemento para mitigar os efeitos daquela legislação de imediato pós-guerra civil. ${ }^{14}$

Embora os Códigos Negros tenham sido legalmente combatidos, seus efeitos se estenderam pelo tempo. As formas de relacionamento econômico que foram esboçados durante a sua vigência serviram de modelo para o cenário de exploração ao qual o negro do sul do país estaria submetido. Praticamente impossibilitado de cultivar o seu próprio espaço de terra, teve de se sujeitar a outros tipos de acordos trabalhistas que, da mesma forma, caracterizariam o período mais turbulento que estaria por vir. Dentre esses acordos, o mais conhecido era o esquema de divisão da produção entre o proprietário de terras e os meeiros ou "sharecroppers". Para Cuthbert-Kerr (2008, p. 79), a necessidade de se manter a força de trabalho era mais importante que restabelecer as normas sociais e culturais de antes da guerra e estão no cerne da criação dos Códigos Negros. Contudo, a estruturação de sistemas políticos e judiciários tendenciosos e alicerçados em um viés racial proporcionaram a configuração de uma convivência entre brancos e negros em que demonstrações formais e informais de racismo eram entendidas como naturais naquela sociedade. Como descrito por Packard (2011, p. 40), a vasta maioria dos brancos do sul não tinha a menor dúvida da necessidade de um relacionamento baseado na questão racial para substituir o que a derrota militar tinha lhes custado.

dois vetos do presidente Johnson, que a via como estabelecendo proteção demasiada aos negros, o Congresso a aprovou marcando, dessa forma, a força do governo federal frente aos estados. Cf. WEELER, Samuel Paul. Civil Rights Act of 1866. In: ALEXANDER, Leslie M.; RUCKER, Walter C. (eds.), op. cit., 2010, p. 698-699.

${ }^{13}$ Atos realizados pelo Congresso para reger a política sulista pós-guerra e fazer com que os estados da região respeitassem a condição de homens livres dos antigos escravos. Divididos em cinco distritos militares, os governos estaduais deveriam garantir o direito de sufrágio dos afro-americanos, dentre outras medidas, caso pretendessem ser readmitidos à União. Ver: DAWSON III, Joseph G. Military Reconstruction Acts (1867-1868). In: ZUCZEK, Richard (ed.), op. cit., 206, p. 406-410.

${ }^{14}$ A Décima Quarta Emenda à Constituição dos Estados Unidos, ratificada em 28 de julho de 1868, garantia o direito à cidadania de todas as pessoas nascidas ou naturalizadas no país e a legítima proteção destas de acordo com a lei.

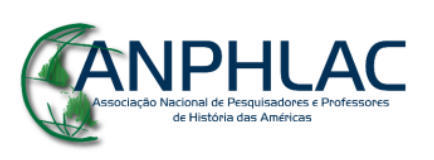

Revista Eletrônica da ANPHLAC, ISSN 1679-1061, № 27, p. 103-143, Ago./, Dez., 2019. http://revista.anphlac.org.br 


\section{A questão racial se intensifica}

O processo de degradação nas condições de vida dos negros norte-americanos nas décadas que se seguiram ao conflito civil foi consideravelmente debatido. Dois dos principais expoentes dessa discussão são Rayford Logan e C. Vann Woodward. A interpretação desenvolvida pelo proeminente historiador afro-americano Rayford Logan (1954 e 1965) procurou apresentar como fator determinante para a degradação da situação do negro nos Estados Unidos os resultados advindos do que ficou conhecido como o Compromisso de 1877, no qual o candidato democrata Samuel Tilden teria aberto mão de seus anseios presidenciais ao republicano Rutherford B. Hayes em troca da desmilitarização do sul e da não intervenção federal nos assuntos internos da região. Tal fato teria definido tragicamente o destino dos antigos escravos e é considerado o evento que finaliza o período conhecido como Reconstrução.

De maneira divergente, embora não negligenciando os desdobramentos advindos dessa conjuntura, Woodward (1955) destaca que a gradativa perda de direitos dos negros se desenrolou a partir de uma série de processos que se evidenciaram a partir de 1890 . Para esse historiador, o status social a ser ocupado por aquela parcela da população foi se ajustando por intermédio de conflitos econômicos e políticos entre os brancos que tiveram solução às custas dos negros.

A situação do afro-americano na Era Progressista submetido às leis Jim Crow encontrou desdobramentos em todos os aspectos de sua existência. Os principais deles estavam relacionados à determinação de excluí-lo dos contextos político e econômico. Contudo, o panorama ideológico não pode ser deixado de lado quando estamos tratando de uma sociedade na qual as relações sociais se encontram reguladas na percepção que determinada camada tem sobre o outro.

$\mathrm{Na}$ virada do século XX e em seus anos iniciais, era tida como comum a classificação de seres humanos em escalas de evolução, sendo que nos Estados Unidos essa divisão toma proporções ainda mais alarmantes. Ainda no século XIX, o universo acadêmico e científico norte-americano debatia veemente o que acreditavam ser os elementos que diferenciavam os seres humanos, como densidade do crânio ou fatores

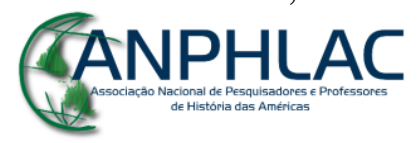

Revista Eletrônica da ANPHLAC, ISSN 1679-1061, № 27, p. 103-143, Ago./, Dez., 2019. http://revista.anphlac.org.br 
ambientais. Atentos às discussões que se avolumaram no período anterior à abolição, os escravistas se apropriaram desses discursos para legitimar seu trato para com os negros. Discutindo a estruturação das teorias racistas nos Estados Unidos, na primeira metade do século, Luciana da Cruz Brito (2014) aborda como as ideias em torno do poligenismo ganharam as atenções da sociedade sulista. ${ }^{15}$ Dentre os defensores dessa teoria, estava o médico Josiah Nott, para quem brancos e negros eram espécies distintas e o relacionamento entre os dois poderia causar a degradação dos brancos estadunidenses.

Influenciados pelas pregações do Darwinismo Social, intelectuais brancos norteamericanos procuraram entender o desenvolvimento acentuado de seu país como um desdobramento de sua superioridade em relação aos demais grupos sociais, destacadamente àqueles entendidos como o outro extremo. O chamado Darwinismo Social, termo empregado para associar as conjecturas darwinistas à estrutura social, denotou por parte de seus teóricos uma ampla gama de interpretações, desde variações que apresentaram um caráter radical sobre a luta que se daria em uma espécie de arena ocupada pelos seres humanos até análises mais brandas acerca da trajetória das sociedades em direção à evolução. ${ }^{16}$

No contexto no qual se desenvolve o que se costumou definir como progressismo, o país procurou maneiras de sanar as feridas ainda abertas pela Guerra Civil. Nesse processo, o que se convencionou interpretar como o que significava ser americano liberdades individuais, apreço pelas instituições democráticas, senso de união, etc. - tinha sido abalado pelos anos de "guerra entre irmãos". Analisando o contexto de reestruturação dos Estados Unidos, no período compreendido entre o fim da Reconstrução e o início da década de 1920, o historiador Jackson Lears (2009, p. 1), descreve-o como um processo de

\footnotetext{
${ }^{15}$ Poligenismo é uma definição que procura relacionar o surgimento do homem ligado a várias origens. Diferentemente do monogenismo, que trata do surgimento dos seres humanos oriundos de uma mesma raiz genealógica, tendo em Adão e Eva seus progenitores, a forma como estudiosos apresentavam suas ideias para a classe escravista, afirmando, por exemplo, que indivíduos não-brancos não eram humanos, era suficiente para solucionarem seus dilemas religiosos e morais. Para saber mais, ver: GOULD, Stephen Jay. The mismeasure of man. New York: W. W. Norton \& Company, 1996.

${ }^{16}$ Para saber mais sobre o termo, ver: HAWKINS, Mike. Social Darwinism in European and American thought, 1860-1945: nature as a model and nature as threat. Cambridge: Cambridge University Press, 1997 e SINGER, Peter. A Darwinian Left: politics, evolution and cooperation. New Haven: Yale University Press, [1999] 2000.
}

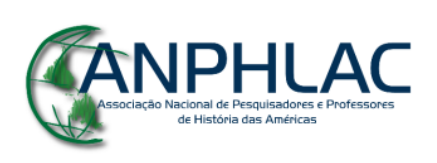

Revista Eletrônica da ANPHLAC, ISSN 1679-1061, № 27, p. 103-143, Ago./, Dez., 2019. http://revista.anphlac.org.br 
"renascimento da nação" que, dentre suas diversificadas formas, abrangia um esquema de regeneração em escala espiritual, moral e física. Tal estrutura contava com perspectivas norte-americanas que evidenciavam uma renovada visão em relação a preceitos de raça e império. Esse novo posicionamento contribui para explicar muito da estratégia norte-americana em relação à política externa pós-guerra civil, bem como novas diretrizes quanto à configuração e ao fortalecimento da supremacia branca em sua política nacional. O sucesso que proporcionou esse tipo de estrutura estava diretamente ligado a uma predisposição dos estadunidenses em desenvolverem tal regeneração tendo por base o reforço ao culto da força. Nesse processo, o afro-americano estava na posição mais crítica. De acordo com Lears,

\footnotetext{
A era da regeneração coincidiu com o apogeu do racismo científico, na qual legitimou a supremacia branca em casa e o império no exterior. Por décadas seguindo o fim da Reconstrução, o terror racial e a legislação Jim Crow se combinaram para garantir que o renascimento de uma nação seria designado somente para os brancos (LEARS, 2009, pp. 10-11, tradução livre).
}

Ainda levando em conta percepções ideológicas de inferioridade e superioridade racial na sociedade em transformação do período, questionamentos em relação à aura progressista de determinados agentes se tornaram evidentes. Segundo Leonard (2016, p. xi), intelectuais e ativistas do movimento apresentavam ideias e pregavam ações que podem ser tidas como contraditórias para o que possa ser entendido hoje como progressista. As questões nacionais que ficaram aparentes com o fim do século XIX depressão econômica, conflitos trabalhistas, o grande negócio, por exemplo - deveriam ser de alguma forma supervisionadas e regulamentadas por uma administração estatal capacitada para tal fim. Nesse contexto, o gerenciamento das questões econômicas estaria nas mãos de novas e independentes agências do governo compostas por um corpo de burocratas altamente capacitado para administrar a economia americana tendo como objetivo o bem de todos. O estado moderno pregado pelos reformadores deveria ser guiado por procedimentos científicos.

Em sua campanha para reformar a sociedade norte-americana da virada do século XX, praticaram, no entanto, um discurso de exclusão de elementos que não eram

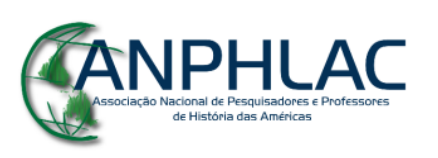

Revista Eletrônica da ANPHLAC, ISSN 1679-1061, № 27, p. 103-143, Ago./, Dez., 2019. http://revista.anphlac.org.br 
considerados legítimos representantes dos interesses nacionais. Dentre eles, os imigrantes, os afro-americanos, o incapacitado, tanto mental quanto tecnicamente, e as mulheres. Esses elementos, segundo a exposição de Leonard (2016, p. xii), eram vistos pelos reformadores como uma ameaça à integridade racial anglo-saxônica por aceitarem salários inferiores ao do trabalhador americano. A militância em advogar uma regulamentação para o salário dos trabalhadores e horas de trabalho teria como objetivo remover aqueles elementos da competição econômica nacional. Tal propósito, da mesma forma que a administração estatal deveria ser controlada por um corpo de tecnocratas, encontrou nas pregações científicas de inferioridade e superioridade entre os seres humanos a sua base de legitimidade.

A ampliação acerca da suposta inferioridade do afro-americano contribuiu sobremaneira para o rebaixamento de sua condição a elemento indesejado no ambiente estadunidense. Dentre as principais características que definem as relações sociais do período durante o qual as manifestações das leis Jim Crow eram costumeiras está a prática da violência física perpetrada contra o negro no país. A prática social do linchamento tinha como objetivo perpetrar uma punição rápida e "exemplar" àqueles elementos que, de alguma forma, desafiavam convenções da comunidade. Durante anos, essa era uma ação difundida em estados de fronteira do oeste e tinha em indivíduos brancos suas principais vítimas. No entanto, nota-se uma alteração na forma como tais eventos eram perpetrados. De acordo com Brundage (1993, p. 8), a proporção de linchamentos ocorridos nos estados do sul durante os anos de 1880 e 1920 foi de mais de $90 \%$ de todos os casos do país. Enquanto o meio-oeste registrou em torno de 181 pessoas brancas e 79 pessoas negras linchadas durante aquele período, o sul apresentou 723 e 3220 assassinatos de brancos e negros, respectivamente, revelando assim a relação entre o fenômeno do linchamento e o problema da questão racial. De igual maneira, para Stephens (1999, pp. 655-671), tais manifestações racistas violentas fizeram parte de um contexto de institucionalização da supremacia branca, que a partir da abolição não via mais os negros como uma propriedade valiosa.

\section{CANPHLAC}

Revista Eletrônica da ANPHLAC, ISSN 1679-1061, № 27, p. 103-143, Ago./, Dez., 2019.

http://revista.anphlac.org.br 


\section{Segregação política e econômica}

Como demonstrado até o momento, o elemento ideológico se mostra crucial para se compreender o tratamento que seria destinado ao afro-americano, tanto por aqueles responsáveis para tal fim quanto pela população em geral. No entanto, o fator que mais parece estar relacionado à degradação da forma de vida do negro, pelo menos na região sul, está associado à pretensão de privá-lo do processo eleitoral. De acordo com Wang (2006, p. 202), podem ser estabelecidos dois períodos que descrevem a privação de direitos políticos da parcela negra da população. A primeira parte dessa estratégia teria se estruturado entre os anos que compreendem a segunda metade da década de 1870 e fins de 1880. Durante esses anos, os métodos utilizados pelos Democratas, conhecidos como "redentores" por terem retomado as rédeas da configuração política local, variaram desde práticas de influência do eleitorado por meio de pequenos favores ou do uso da violência, até a manipulação do sistema de votação e fraudes.

Mesmo nesse primeiro período, formas de protesto e manifestações contrárias dos negros fizeram parte de suas pretensões para impedirem a propagação daquele estado de coisas. Exemplo dos mais marcantes sobre as pretensões daqueles que advogavam a supremacia branca no sul é o da cidade de Colfax, estado da Louisiana, em 1873. As tentativas de reassumir o controle político dos estados da região sempre estiveram nas mentes dos Democratas e a iminente derrota para o governo do estado exaltou os ânimos dos cidadãos brancos locais a ponto de formarem uma milícia aos moldes da $K u$ Klux Klan. A White League (Liga Branca) intimidava os cidadãos negros e seus aliados brancos que lutavam para expandir os direitos adquiridos após a guerra civil. Com o intuito de defender o fórum local, um grupo de afro-americanos entrou em conflito com a Liga Branca e foi obrigado a se render. Mesmo após a rendição, vários negros foram assassinados, deixando um saldo de aproximadamente 150 negros e três brancos mortos. O Massacre de Colfax é muitas vezes tido como um "riot" (motim, em inglês). No entanto, segundo a historiadora LeeAnna Keith (2008, p. xiii), aplicar o termo riot a determinados incidentes de cunho racial pode ser visto como uma tendência dos racistas

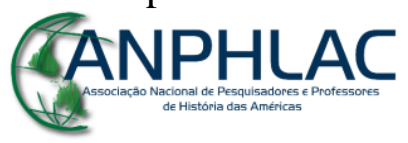

Revista Eletrônica da ANPHLAC, ISSN 1679-1061, № 27, p. 103-143, Ago./, Dez., 2019. http://revista.anphlac.org.br 
brancos na formação de opinião pública que pregava a situação caótica da região após o processo de emancipação. Para Keith, o que de fato aconteceu foi um massacre evidenciado, até mesmo pelo número de negros executados após o conflito: um total de 48 prisioneiros.

A segunda etapa dessa articulação de excluir os direitos políticos dos negros se apresentou mais determinada e estava estruturada na edificação de mecanismos legais cujo objetivo era a completa supressão de seu poder de voto. A aplicação de sucessivos artifícios legislativos tinha como preocupação sua efetividade apenas ao que cabia o voto dos negros de forma que não violassem as prerrogativas da Décima Quinta Emenda constitucional. ${ }^{17}$ Nesse processo, a partir de 1889, vários estados sulistas começaram a promover convenções para revisarem suas constituições, principalmente no tocante ao direito ao sufrágio.

Os exemplos para limitar a presença dos negros nos processos eleitorais variavam consideravelmente. Estados como a Flórida e o Tennessee estabeleceram como prérequisito para a participação em pleitos eleitorais o pagamento de uma taxa. Outros estados seguiram o mesmo caminho, mas além dessa determinação procuraram estruturar outros mecanismos de privação, temendo que tal prerrogativa pudesse reduzir o eleitorado constituído por brancos pobres. Foi assim que o Mississippi adotou a understanding clause (cláusula de entendimento ou compreensão) em 1890. Esse foi um elemento complementar que dizia respeito aos testes de alfabetização. Por essa medida, os votantes em potencial deveriam ler e interpretar certas passagens da Constituição estadual sob a presença de um supervisor. Apesar de indivíduos negros e brancos serem submetidos ao mesmo teste, o poder dado aos oficiais estaduais de julgar os resultados descambava para mais uma forma injusta e desleal de privação política em relação aos primeiros. A Louisiana, por sua vez, acrescentou em sua constituição, em 1898, a grandfather clause (cláusula do avô), cuja prerrogativa delegava direito de voto a todos aqueles que antes de

\footnotetext{
${ }^{17}$ Emenda ratificada em 30 de março de 1870 que garantia o direito ao sufrágio de todos os cidadãos norteamericanos, proibindo o governo federal e os estados de lhe negar em razão de raça, cor ou situação anterior de servidão.
}

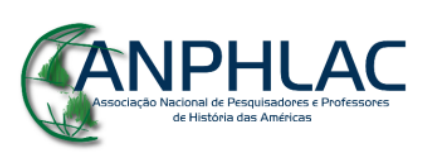

Revista Eletrônica da ANPHLAC, ISSN 1679-1061, № 27, p. 103-143, Ago./, Dez., 2019.

http://revista.anphlac.org.br 
1867, ano de concessão ao direito de sufrágio aos negros, tivessem totais condições de serem elegíveis ou que fossem filhos ou netos de pessoas em tais condições. ${ }^{18}$

Os resultados dessas e de outras medidas foram sentidos rapidamente. Como demonstrado por Wang (2006, p. 205), dois anos após o Mississippi alterar a sua Constituição, dos 147.000 afro-americanos em condições para exercer seu direito de voto no pleito anterior, apenas 9.036 foram considerados aptos a se registrarem. Na Louisiana, dos 130.000 registrados, em 1896, apenas 5.320 conseguiram tal feito em 1900. Quatro anos depois, 1.342 foram capazes de se registrarem.

A segregação proporcionada pelas leis Jim Crow, durante as décadas de 1890 e 1920, estendeu seus tentáculos por todos os aspectos da vida dos negros norte-americanos. No que se refere ao campo econômico, as opções para a busca de uma vida melhor se mostraram de igual maneira escassas. Como citado anteriormente, após a emancipação, as promessas de uma seguridade financeira para os antigos escravos esbarraram em diversas medidas que tinham o intuito de mantê-los ligados aos seus antigos senhores e suas terras. Dentre os sistemas de trabalho que dominavam a paisagem sulista do pósguerra civil, e que se estendeu por décadas, está o contrato por divisão de produção.

Inicialmente, essa forma de contrato foi visto com positividade tanto por nortistas quanto por sulistas. De acordo com Burton (2006, pp. 565-566), para aqueles, o esquema de trabalho poderia contribuir para que os recém libertos aprendessem as "virtudes" capitalistas da autodisciplina, indústria, parcimônia e iniciativa. Os sulistas, por seu lado, incapazes de pagarem salários com regularidade, teriam a chance de reestruturar a economia regional sem perderem suas propriedades. Com a retomada do poder político pelos adeptos da supremacia branca, o sistema se voltou a mais uma forma de exploração da mão-de-obra negra. Com os contratos sendo mais verbais que acordos formais e devido ao índice de analfabetismo elevado dos afro-americanos, o caminho estava aberto para a enganação no momento de divisão da produção. Segundo Stanton (2008, p. 726), os meeiros podiam ficar com apenas 25 por cento, ou menos, de tudo que produziam após quitarem outros débitos, como a aquisição de suprimentos.

\footnotetext{
${ }^{18} \mathrm{Cf}$. Constitution of the State of Louisiana, 1898, Article 197.

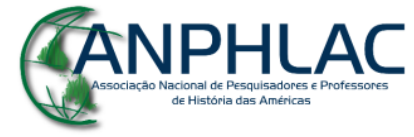

Revista Eletrônica da ANPHLAC, ISSN 1679-1061, № 27, p. 103-143, Ago./, Dez., 2019. http://revista.anphlac.org.br
} 
Essa forma de trabalho representava uma de duas outras formas de acordos entre fazendeiros e trabalhadores. Existiam ainda, de acordo com Stanton (2008, p. 726), os tenant farmers (colonos/arrendatários), que alugavam uma porção da terra a preço fixo e que provavelmente possuíam suas próprias ferramentas e o share renting, em que o inquilino, recebendo algumas facilidades do senhor da terra, comprometia-se em compartilhar de um quarto a um terço da colheita. Nesses dois últimos exemplos, a maior parte dos trabalhadores eram brancos.

Nesse sentido, a condição de meeiro pode ser considerada a mais desigual das três, a ponto de organizações serem criadas com o objetivo de regular tal situação. Inicialmente pode ser mencionada a Colored Farmers Alliance, estabelecida no Mississippi em 1888. Essa organização tinha como objetivo proporcionar maiores liberdades para os seus membros afirmando que estes tinham o direito de comercializar com lojas e cooperativas fora de sua localidade, o Condado de Leflore. Sendo comparada às insurreições escravas, os fazendeiros locais fizeram de tudo pela sua eliminação e, um ano depois, um conflito entre os membros da organização e uma milícia estadual deixou no mínimo 25 afroamericanos mortos, fazendo com que o evento fosse conhecido como "O massacre do Condado de Leflore".

As atividades econômicas exercidas pelos afro-americanos no período durante o qual não estavam envolvidos diretamente com o setor agrário, da mesma maneira, evidencia as condições segregacionistas que regiam a vida daquele grupo social. De acordo com Piott (2011, p. 187), menos de três por cento dos negros estadunidenses exerciam trabalhos em que eram exigidas maiores habilidades técnicas. Por volta de 1910, dos 28.674 trabalhadores na indústria de turpentine (terebintina), utilizada para a fabricação de solventes e considerada uma das piores atividades econômicas do período, 24.647 vagas eram ocupadas por cidadãos negros. Na indústria de tabaco, metade dos empregos era ocupada por negros, mas exerciam atividades de transporte e de remoção de folhas com as mãos. Na indústria têxtil, eram praticamente excluídos, pois essa atividade era preferencialmente exercida por brancos pobres como uma tática para se evitar que tal parcela decaísse abaixo da condição econômica do afro-americano.

\section{CANPHLAC}


Segundo Myrdal (1944, p. 293-294), nos estados do norte podia ser verificado que entre os anos de 1890 e 1910, houve um aumento no número de trabalhadores negros do sexo masculino em uma taxa de aproximadamente 160.000 , exercendo serviços tais como domésticos, cozinheiros, garçons, encarregados de limpeza e barbeiros. No entanto, durante os anos de 1910 e 1930, o número de trabalhadores atingiu um índice de aproximadamente 480.000 , todavia ocupando basicamente os mesmos cargos.

Embora se tenha a convicção de que as relações envolvendo brancos e negros no sul dos Estados Unidos eram mais acentuadas em termos de disparidades sociais, no norte do país também podem ser verificadas práticas de discriminação tendo por base o fator cor. De acordo com Sugrue (2008, p. 131), as cidades da região estavam invisivelmente divididas pela raça e nelas podiam ser encontrados hotéis e restaurantes que atendiam a um determinado seguimento da população. Outros locais de socialização, como parques de diversões, pistas de boliche e de patinação, muitas vezes restringiam o acesso dos afroamericanos ou permitiam sua entrada em determinados dias.

Outros aspectos da vida dos afro-americanos mostram uma condição quase que inimaginável. No que se refere à disparidade entre as verbas destinadas à educação de brancos e negros, esse aspecto revela nitidamente o descaso e a intenção de mantê-los permanentemente no estrato mais baixo da sociedade americana. De acordo com Fairclough (2002, p. 52), no caso sulista, até 1900 as escolas destinadas a atender estudantes brancos eram tão pobres quanto às escolas para negros. No entanto, o aumento das verbas direcionadas ao ensino público veio acompanhado de práticas de discriminação. Em estados como a Carolina do Norte, onde a população negra em idade escolar era de 34 por cento em 1900, o dinheiro disponibilizado para essa população chegava aos 28 por cento. Porém, por volta de 1915, os fundos disponíveis para eles tinham caído para não mais que 13 por cento. Em outro estado, a Carolina do Sul, para cada dólar gasto na educação de uma criança negra, no mesmo período, uma criança branca recebia 5.75 dólares, enquanto que em 1915, a diferença entre uma e outra era de vinte vezes.

Em meio a situações tão degradantes, reflexos eram sentidos na perspectiva de vida e estabilidade familiar. Segundo Piott (2011, p. 189), a expectativa de vida dos

$$
\text { CANPHLAC }
$$


homens negros era de 32,5 anos, significando 16 anos a menos que os homens brancos. $\mathrm{Na}$ Carolina do Sul, 16 por cento dos bebês afro-americanos morriam antes de completarem um ano de idade. Essa mortandade elevada de homens negros fez com que durante a Era Progressista, 20 por cento das mulheres entre 33 e 45 anos fossem viúvas. Dessa forma, 20 por cento dos lares em Chicago, aproximadamente 24 por cento em Nova Iorque e 34 por cento das áreas urbanas da Geórgia eram chefiadas por mulheres.

O processo de deslocamento de grande contingente de afro-americanos para as regiões urbanizadas do norte, iniciado em fins do século XIX, que se estendeu até a segunda metade do século XX, e que ficou conhecido como Grande Migração, apesar de representar uma melhora nas condições de vida das famílias negras que deixavam o sul, contribuiu para fomentar as tensões raciais nas cidades industrializadas da região. O ápice dessa relação conflituosa foi o ano de 1919, quando diversos distúrbios de caráter racial tomaram conta de várias cidades do norte. Esses eventos, popularmente conhecidos como Red Summer (Verão Vermelho), encontram na cidade de Chicago um dos seus exemplos mais característicos. A comoção e a revolta pela morte de um jovem afro-americano, Eugene Williams, atiçaram também os ânimos de boa parte da população branca, que começou a promover atos de repressão contra as atividades dos negros. O início dos distúrbios na cidade, em 27 de julho, representou, nas palavras de Tuttle, Jr. (1996, p. 11), uma característica da violência racial urbana que viria a se tornar um problema nacional nos anos iniciais do século XX.

Nos sistemas policial e penal, pode-se atestar o viés racial quanto à detenção e ao encarceramento dos negros norte-americanos. Sendo o corpo policial constituído basicamente por brancos pobres, o poder dado aos agentes de repressão se transfigurava em mais um meio de demonstrar a ideologia da supremacia branca que estes carregavam. Inseridos no sistema penal, as punições destinadas aos negros eram inacreditavelmente mais elevadas que a dos brancos. Além disso, grande parte dos afro-americanos que cumpriam penas estavam inseridos em sistemas de trabalho como o convict lease system, no qual o condenado era "arrendado" para prestar serviço a uma empresa privada. Após críticas e a comparação de que se tratava de uma nova forma de escravidão, o sistema foi

\section{GANPHLAC}

Revista Eletrônica da ANPHLAC, ISSN 1679-1061, № 27, p. 103-143, Ago./, Dez., 2019.

http://revista.anphlac.org.br 
modificado e o condenado passou a exercer seus trabalhos acorrentado para os estados, no que ficou conhecido como chain gang system.

\section{Mobilização e resistência contra a segregação progressista}

De todas as questões que fizeram parte da abordagem levada a cabo pelos progressistas ou reformistas, a que diz respeito ao grupo afro-americano se mostrou daquelas que mais permaneceram em evidência. Suas formas de contribuição na resolução de determinadas questões e, por ventura, sua quase inércia no diálogo, exigiram um posicionamento mais ativo dos negros norte-americanos para a conquista de alguma espécie de barganha, o que descarta de imediato qualquer pretensão de passividade do grupo. A análise da forma de atuação desse grupo, durante um período extremamente conturbado da história norte-americana, tem como uma de suas principais premissas salientar o longo processo desencadeado para que os direitos inalienáveis, pregados pelos fundadores da nação, ainda que visto como objeto de retórica, pudessem se tornar uma realidade. Foi, no entanto, no período denominado progressista que uma busca mais enfática aos direitos de cidadania, pregados pelos negros esteve enraizada.

As formas de manifestações encontradas pelos negros norte-americanos para fazer frente às práticas racistas e segregacionistas que vigoravam no país naqueles anos de virada de século se mostraram diversificadas. Podemos citar a criação de associações civis, o papel da imprensa negra e a militância em torno da garantia do direito ao voto.

Durante aquele período, diversas organizações e campanhas foram estruturadas procurando de alguma forma minar o sistema de segregação racial, fosse no sul, onde era mais nítida, ou no norte do país, onde era mascarada. Dentre essas organizações, pode-se citar o Niagara Movement (Movimento Niágara), entendido como uma união de proeminentes afro-americanos, entre os anos de 1905-1910, contra as práticas discriminatórias e segregacionistas que vigoravam pelo país. Para os membros

\section{CANPHLAC}

Revista Eletrônica da ANPHLAC, ISSN 1679-1061, № 27, p. 103-143, Ago./, Dez., 2019.

http://revista.anphlac.org.br 
envolvidos, nada menos que o reconhecimento dos direitos políticos e civis era o objetivo a ser alcançado. ${ }^{19}$

O fato de não contar durante muito tempo com nenhum membro branco em suas fileiras contribuiu para a não efetivação das propostas devido à falta de entendimento sobre as discussões que deveriam ser colocadas em pauta acerca das relações envolvendo brancos e negros no país. Muitas vezes não recebendo o devido crédito que merece, o Movimento Niágara deve ser considerado como uma das mais influentes e pioneiras organizações a desafiar a política Jim Crow nos Estados Unidos, no início do século XX, pavimentando o caminho para outras instituições mais efetivas, como a National Association for the Advancement of Colored People - NAACP (Associação Nacional para o Avanço das Pessoas de Cor).

A NAACP, por sua vez, representou, e ainda representa, uma das maiores ferramentas do negro norte-americano em prol de maiores igualdades de direitos. ${ }^{20}$ Fundada em 1909 por brancos de tendência progressista e contando com a participação de líderes da comunidade negra, segundo Meier e Bracey, Jr. (1993, p. 7), tem ligações com o reformismo do século XIX por contar em sua estrutura com descendentes de abolicionistas brancos e de veteranos de antigas organizações de ajuda aos negros, tais como a Afro-American League. Diferentemente de várias associações que ignoravam o problema racial, a NAACP procurou a partir dos próprios preceitos defendidos pelos progressistas, tais como a crença no papel do Estado para a garantia da ordem social, levar adiante sua proposta de aversão às práticas discriminatórias que até hoje assombram os negros norte-americanos. Entre seus membros fundadores estão William English Walling, escritor e socialista que dedicou grande parte de sua vida ao movimento trabalhista, Oswald Garrison Villard, neto do antigo abolicionista William Lloyd Garrison, Mary White Ovington, assistente social dedicada a diversas causas dos negros

\footnotetext{
${ }^{19}$ Para um maior conhecimento sobre o Movimento Niágara e os momentos iniciais do movimento pelos direitos civis, ver: JONES, Angela. African American civil rights: early activism and the Niagara Movement. Santa Barbara, Denver, Oxford: Praeger, 2011.

${ }^{20}$ Para uma análise sobre os maiores desafios enfrentados pela instituição, ver: JONAS, Gilbert. Freedom's Sword: the NAACP and the struggle against racism in America, 1909-1969. New York: Routledge, 2005 e VERNEY, Kevern; SARTAIN, Lee (Eds.). Long is the way and hard: one hundred years of the NAACP. Fayetteville: University of Arkansas Press, 2009.
}

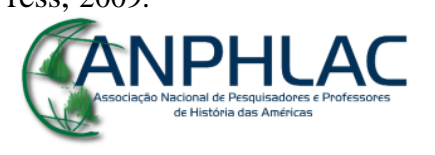

Revista Eletrônica da ANPHLAC, ISSN 1679-1061, № 27, p. 103-143, Ago./, Dez., 2019. http://revista.anphlac.org.br 
estadunidenses, e W. E. B. Du Bois, ativista e primeiro afro-americano a receber o título de doutorado na Universidade Harvard, em 1895.

Essa diferenciação em sua estrutura organizacional, incluindo membros brancos e negros, permitiu uma maior visibilidade à organização, bem como a percepção de que o ativismo proveniente de sua configuração seria algo mais bem estruturado. Nesse aspecto, a contribuição de Du Bois permitiu uma maior aproximação com a comunidade negra, já que começava a se tornar um dos porta-vozes do grupo. Seus trabalhos acadêmicos e literários começavam a lhe proporcionar destaque nos debates em que a questão da relação racial estivesse em pauta. Como professor na Universidade de Atlanta, estado da Geórgia, promoveu ciclos de leituras e debates, além de organizar exposições que revelavam o desenvolvimento empreendido pelos negros do país e do estado, mesmo submetidos às leis Jim Crow. Em 1900, Du Bois organizou uma compilação de fotografias que foram apresentadas na Exposição Universal de Paris. Contudo, um dos maiores empreendimentos de Du Bois pode ser considerado a criação da revista The Crisis, em 1910, tendo seguido como editor do periódico até 1934. Essa revista, órgão oficial de propaganda da NAACP, muitas vezes representou não a voz da instituição, mas a de seu editor, o que ocasionou diversos conflitos entre outros membros da associação. ${ }^{21}$

Embora Du Bois tenha sido extremamente importante para a NAACP, sendo até hoje lembrado como seu principal ícone, esforçando-se por estabelecer e levar adiante a edição da revista The Crisis, seu temperamento contribuiu de forma significativa para o surgimento de atritos que por diversas vezes colocaram em risco o andamento da publicação. Um desses atritos foi com Villard que, de acordo com Lewis (1993, p. 409), pretendia estabelecer controle sobre as publicações de Du Bois, consideradas radicais demais para o período, o que se evidenciou um erro. Para Arndt (1971, p. 187), a aliança entre Du Bois e a NAACP pode ser pautada mais por uma conveniência que por uma convicção harmoniosa. Nesse sentido, os dois tinham a ganhar. Du Bois tinha em suas

\footnotetext{
${ }^{21}$ Para saber mais sobre a vida pessoal e profissional desse grande ativista, ver: DU BOIS, W. E. B. The Autobiography of W. E. B. Du Bois: A Soliloquy on Viewing My Life from the Last Decade of Its First Century. New York: International Publishers, [1968] 1988. Ver também: NASCIMENTO, Carlos Alexandre da Silva. Representando o "Novo" Negro Norte-Americano: W. E. B. Du Bois e a Revista The Crisis, 19101920. Dissertação de Mestrado em História Social, FFLCH-USP, São Paulo, 2015.
}

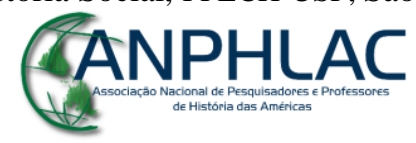

Revista Eletrônica da ANPHLAC, ISSN 1679-1061, № 27, p. 103-143, Ago./, Dez., 2019. http://revista.anphlac.org.br 
mãos um órgão de publicação como forma de expandir suas ideias e a NAACP podia contar em seu plantel com um dos maiores intelectuais do seu tempo. Além disso, a ampla maioria dos membros a associação era constituída por brancos, o que alimentava em Du Bois a desconfiança sobre se eles teriam uma forte disposição para combater o racismo e a segregação de uma maneira efetiva.

Umas das primeiras medidas adotadas pela associação foi enfatizar a situação alarmante em torno do linchamento de cidadãos negros norte-americanos. No entanto, antes mesmo que seus membros empreendessem campanhas para discutir e expor a questão, outros indivíduos tiveram papel de destaque em sua militância para fazer com que outras pessoas se tornassem cientes do problema.

Dentre aqueles que procuraram disseminar a problemática contida na prática do linchamento de afro-americanos, talvez o nome mais expressivo seja o de Ida B. Wells. A trajetória de Wells, desde muito cedo, parecia refletir o tipo de posição política e ativismo com o qual seria reconhecida. A mais velha de oito irmãos, nascida durante a vigência da escravidão, em 1862, no Mississippi, descreve como uma de suas primeiras lembranças as leituras que fazia para seu pai e um grupo de amigos sobre as questões políticas do período. Sua mudança para o Tennessee, em 1884, definiria significativamente sua trajetória ao se recusar a sentar em um espaço reservado aos negros em um trem. A atitude de reagir com violência contra a determinação do condutor do veículo, algo que pode ser comparado a uma tentativa de suicídio em uma região dominada pelas práticas segregacionistas, mostrou a Wells que o questionamento a tais determinações deveria ser constante. ${ }^{22}$

Wells se destacou na área jornalística sendo sócia do jornal Free Speech and Headlight, em 1889. Antes disso, participando de clubes sociais que se reuniam para discutir literatura, música, cultura e diversas outras questões, conseguiu se tornar editora de um pequeno periódico, o Evening Star. Após esse fato, uma série de convites solicitando contribuições e escritos de Wells chegava às suas mãos. Em 1892, após

\footnotetext{
${ }^{22}$ Para saber mais, ver: WELLS, Ida B. Crusade for justice: the autobiography of Ida B. Wells. Alfreda M. Duster (Ed.). Chicago; London: The University of Chicago Press, 1970. (Negro American Biographies and Autobiographies).
}

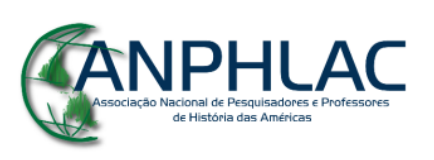

Revista Eletrônica da ANPHLAC, ISSN 1679-1061, № 27, p. 103-143, Ago./, Dez., 2019. http://revista.anphlac.org.br 
escrever artigos sobre o que achava ser o real motivo do assassinato de três empreendedores negros - o intuito de manter a submissão econômica dos negros em relação aos brancos - e de incentivar boicotes e migração, Wells passou a ser ameaçada e não pôde retomar seus trabalhos no Free Speech. O jornal foi atacado e destruído por uma multidão branca em maio de $1892 .{ }^{23}$ A temática envolvendo linchamentos de afroamericanos foi o ponto central nos escritos de Wells. A compilação desses escritos, publicados entre o final dos anos 1890 e início de 1900, deu origem ao livro On Lynching (2014), que traz, por exemplo, as estatísticas e as causas alegadas das ocorrências entre os anos 1892 e 1894, contidas no livro A Red Record, publicado originalmente em 1895.

Entre os anos de 1893 e 1894, Wells empreendeu fora dos Estados Unidos duas campanhas contra o linchamento de afro-americanos. Na edição do dia 26 de julho de 1894, o jornal The Sun, da cidade de Nova Iorque, publicou uma entrevista na qual a ativista descreve seu trabalho na Europa, em que pode ser traçado um pouco de sua rotina. Podem ser elencados diversos debates em congregações religiosas e clubes sociais, e até mesmo o esforço em induzir organizações trabalhistas nas cidades inglesas de Leeds e Bradford a aprovarem resoluções dissuadindo emigrantes a evitarem o sul dos Estados Unidos até que a violência contra o negro tivesse sido suspensa. ${ }^{24}$

Em 30 de julho, o mesmo The Sun publicou um discurso realizado por ela em uma igreja metodista local, que, dentre outros ouvintes, contou com a presença de T. Thomas Fortune, ativista e jornalista editor do jornal The New York Age. Dentre os tópicos levantados em seu pronunciamento, Wells destacou que apesar da Proclamação de Emancipação (1863) e três emendas constitucionais, o negro no país ainda não poderia ser considerado uma pessoa livre. Wells salientou também o interesse de jornais ingleses em saber o motivo que a impelia a promover tal militância no exterior, ao que teria respondido ser aquela a única forma de alcançar os americanos, que até então os negros estavam combatendo em vão por reconhecimento e que o grupo negro tinha decidido

\footnotetext{
${ }^{23}$ Para saber mais, ver: Ida B. Wells-Barnett (1862-1931). In: KNIGHT, Gladys L. Icons of African American protest: trailblazing activists of the civil rights movement. Westport, Connecticut; London: Greenwood Press, v.2, 2009, p. 519-543.

${ }^{24}$ The Sun, 26 de julho de 1894, p. 7. Esta entrevista foi reproduzida pelo jornal The Daily Inter-Ocean, da cidade de Chicago, em agosto. Cf. The Daily Inter-Ocean, 4 de agosto de 1894, Vol. XXIII, №. 133, p. 9.
}

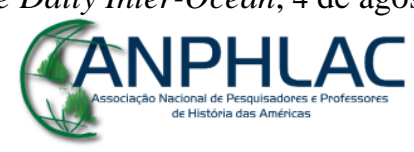

Revista Eletrônica da ANPHLAC, ISSN 1679-1061, № 27, p. 103-143, Ago./, Dez., 2019. http://revista.anphlac.org.br 
deixar outras pessoas conhecerem o estado das coisas e ver se algum benefício não poderia ser alcançado de tal forma. ${ }^{25}$

Em sua articulação para chamar a atenção da sociedade, a NAACP se utilizou de vários artifícios com a expectativa de obter resultados mais efetivos. Sendo ela própria originada de um desses eventos, o distúrbio racial ocorrido em Springfield, Illinois, em 14 de agosto de 1908, os efeitos que tal manifestação causou nos membros reunidos em sua configuração foram vistos como a expressão de uma guerra racial, que se expandia por todas as regiões do país. Percepção que foi expressa por um de seus fundadores, William English Walling, no artigo "The Race War in the North”, publicado no jornal The Independent, em 03 de setembro de $1908 .^{26}$

Após a fundação da NAACP, a organização começou a colocar em prática uma tática de investigação de casos particulares envolvendo ocorrências com afro-americanos. Posteriormente, procurou estabelecer um programa mais amplo de combate que deveria abarcar todo o território nacional, sendo que a mudança na forma como as pessoas pensavam a questão estava no foco desse processo. De acordo com Kellogg (1973, p. 210), a NAACP empreendeu pesquisa por informação objetiva, fazia pressão por suporte do governo nacional e estadual e tentou, sem sucesso, mobilizar as lideranças brancas sulistas. Embora tenha advogado por uma legislação com o objetivo de fazer do linchamento um crime punível por uma lei federal, novamente sem sucesso inicial, alcançou a publicidade que desejara. Outra tática empreendida pela Associação foi procurar obter explicações e revelar ao público o que os governadores pensavam sobre tais práticas e o que estavam fazendo para impedi-las.

O ano de 1916 significou um momento histórico para o destino da Associação, dando origem à Campanha Antilinchamento. Esse programa, incentivado pelo advogado de Boston, Philip G. Peabody, que ofereceu uma contribuição no valor de $\$ 1,000$ se a Associação conseguisse reunir mais $\$ 9,000$ até agosto daquele ano, tinha como meta o delineamento de um efetivo compromisso de estruturar medidas para a completa

\footnotetext{
${ }^{25}$ The Sun, July 30, 1894, p. 2.

${ }^{26}$ WALLING, William English. The Race War in the North. In: The Independent, n. 65, Sept. 3, 1908.

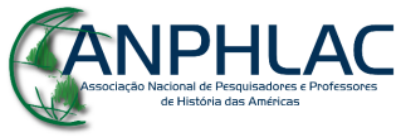

Revista Eletrônica da ANPHLAC, ISSN 1679-1061, № 27, p. 103-143, Ago./, Dez., 2019. http://revista.anphlac.org.br
} 
eliminação daquela prática. Um comitê antilinchamento foi organizado para administrar o fundo e estabelecer os procedimentos que deveriam reger suas formas de atuação. A participação da revista The Crisis para se atingir tal medida foi importantíssima ao solicitar de seus leitores doações para que não se deixassem escapar as contribuições de Peabody e de Moorfield Storey, presidente da NAACP, que também se engajou na campanha. ${ }^{27}$ No número do mês de outubro, a revista The Crisis informou que o valor pretendido tinha sido alcançado com uma pequena folga. ${ }^{28}$

Outra campanha na qual a NAACP precisou se engajar em seus anos iniciais foi o protesto contra a exibição do filme Birth of a Nation (O Nascimento de uma Nação), lançado em 1915. Baseado na obra literária The Clansman (1905), de Thomas Dixon Jr., a produção procura retratar o que foi considerado o fracasso do período de reconstrução, a decadência sulista e a não aptidão do afro-americano para a participação política. Contudo, o elemento que teria elevado os ânimos dos espectadores do filme foi a tão recorrente luxúria atribuída ao homem negro de "possuir" a mulher branca. Algumas reações ao filme podem ser vistas como extremas. Segundo Piott (2011, pp. 199-200), casos de assassinatos de afro-americanos, gritos solicitando o linchamento de um personagem da produção e panfletagem exigindo mais segregação estão entre os exemplos. No entendimento de Woodley (2014, p. 12), para os membros da associação, o filme não apenas retratava uma imagem negativa dos negros, mas reforçava todo preconceito que os brancos mantinham sobre eles. A militância empreendida pela NAACP procurou garantir a não exibição do filme, o que foi conseguido em algumas cidades como Atlantic City e St. Louis, embora temporariamente. A estratégia da NAACP em atuar de acordo com os preceitos do progressismo vigentes na época, como a crítica a qualquer tipo de censura e métodos mais radicais, foi interpretada como um dos elementos responsáveis

\footnotetext{
${ }^{27}$ The Crisis Advertiser (Anti-Lynching Fund). In: The Crisis, v. 12, n. 4, Aug. 1916, p. 202.

${ }^{28} \mathrm{~A}$ soma arrecada pela campanha foi de $\$ 10,177.50$. No entanto a NAACP se viu na necessidade de estender o valor para $\$ 15,000$ demonstrando sua intenção de atingir este novo valor aumentando o número de assinantes de The Crisis. Ver: NAACP. In: The Crisis, v. 12, n. 6, Oct. 1916, p. 275; The Crisis Advertiser. Idem, p. 303.
}

\section{CANPHLAC}

Revista Eletrônica da ANPHLAC, ISSN 1679-1061, № 27, p. 103-143, Ago./, Dez., 2019.

http://revista.anphlac.org.br 
pela falta de sucesso na campanha contra a exibição do filme, além de divisões existentes dentro da comunidade negra. ${ }^{29}$

O negro estadunidense da Era Progressista, além das imagens falsas e estereotipadas que precisava combater, ainda tinha de investir um esforço descomunal no que era visto como a garantia do seu direito mais importante: a manutenção do direito ao voto. Du Bois, em seu livro The Souls of Black Folk (As Almas da Gente Negra), de 1903, já havia se atentado ao fato chegando mesmo a defini-lo como a arma mais importante do mundo moderno (2007, p. 117). A questão do voto era uma temática e preocupação recorrentes e aparece em diversos momentos nesse que é o seu livro mais famoso. Para Du Bois (2007, p. 13), era necessário que os afro-americanos preservassem o poder do voto como uma autodefesa, pois sem ele, corria-se o risco de recaírem em uma segunda escravidão.

Como foi descrito, uma série de leis com o objetivo de privar os negros de seus direitos políticos começou a ser estruturada no início da última década de 1890. As leis Jim Crow, estabelecidas principalmente nos estados do sul do país, representaram um dos mais duros golpes à perspectiva dos negros de serem reconhecidos como cidadãos plenos da república norte-americana. Embora tal legislação tenha sido combatida e revertida, pelo menos formalmente, com o Civil Rights Act (Lei dos Direitos Civis) ${ }^{30}$ e o Voting Rights Act (Lei dos Direitos de Voto) ${ }^{31}$, de 1964 e 1965, respectivamente, a militância em relação à anulação da completa segregação política apresenta um caminho bem mais

\footnotetext{
${ }^{29}$ Ver: The Year of The Birth of a Nation. In: CRIPPS, Thomas. Slow fade to black: the Negro in American film, 1900-1942. Oxford; New York: Oxford University Press, 1993, p. 41-69.

${ }^{30} \mathrm{~A}$ Lei dos Direitos Civis de 1964 significou um marco na longa trajetória empreendida pelos afroamericanos para a conquista e garantia de seus direitos. Esse ato, mais que qualquer outro antes, procurou efetivamente estabelecer métodos de combate a segregação fazendo com que o governo federal decretasse como inconstitucional qualquer medida de exclusão baseada em raça, cor, língua, religião, dentre outras. Cf. RODRIGUEZ, Michael S. Civil Rights Act of 1964. In: ALEXANDER, Leslie M.; RUCKER, Walter C. (Eds.). Op. cit., 2010, p. 701-702.

${ }^{31}$ Lei complementar que se seguiu a promulgação da Lei dos Direitos Civis que tinha por objetivo garantir o direito de voto a todos os cidadãos americanos sem qualquer tipo de imposição discriminatória. Embora encontrando resistência, o Departamento de Justiça ficou a cargo de supervisionar o processo de cadastramento de eleitores fazendo com que o índice de eleitores do Mississippi, por exemplo, fosse de 6 para 44 por cento em 1968. Para saber mais, ver: TRODD, Zoe. Voting Rights Act of 1965. In: ALEXANDER, Leslie M.; RUCKER, Walter C. (Eds.). Op. cit., 2010, p. 1081-1083. Ver também: WALTERS, Ronald W. Freedom Is Not Enough: Black Voters, Black Candidates, and American Presidential Politics. Lanham, MD: Rowman and Littlefield, 2007.
}

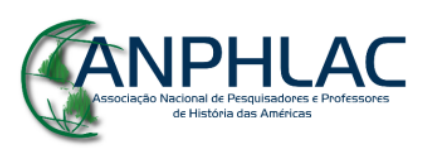


longo. Diversas foram as formas que os negros estadunidenses utilizaram para fazerem jus a tal direito. Segundo Johnson (2008, pp. 231-232), afro-americanos menos escolarizados algumas vezes eram conduzidos até as votações com a perspectiva de verem seus direitos assegurados. Questionamentos na imprensa também podem ser elencados como uma maneira de se posicionar contra o processo de privação política do negro que, foi vista como um dos elementos para que a segregação nos transportes públicos ganhasse força.

Antes da criação da NAACP, o que marca um novo patamar no que se refere à militância para a garantia, preservação e ampliação dos direitos políticos dos afroamericanos, outros tipos de contestação ao impedimento do negro de participar de pleitos eleitorais estiveram presentes durante aquele espaço de tempo. Embora existentes, tais formas de militância não foram vistas como um movimento devido à falta de um suporte institucional, condução em massa de possíveis eleitores e indisposição em desafiar diretamente a supremacia branca sulista. Com o surgimento da NAACP e a estruturação de um corpo permanente de advogados, um posicionamento mais eficaz pôde ser implementado, contribuindo, por exemplo, para tornar inconstitucional a grandfather clause, em 1915.

Formas de atuação e militância podem ser observadas, dentre outras, quando o estado do Alabama, em 1901, procurando reformular sua constituição empreende uma campanha para privar os negros de seus direitos de voto. Petições de protesto, discussões sobre a possibilidade de retorno do negro norte-americano para a África, pronunciamentos mais exacerbados na imprensa estavam em voga durante aquele cenário de exclusão. ${ }^{32} \mathrm{Na}$ tentativa de se evitar um agravamento na situação dos afro-americanos no estado, o líder afro-americano Booker T. Washington em cooperação com mais vinte três simpatizantes escreveram para o presidente da convenção constitucional do estado, John B. Knox, relatando suas preocupações sobre o agravamento das relações raciais caso

\footnotetext{
${ }^{32}$ Para saber mais a respeito das formas de manifestação política, ver: Negroes have organized: Alabama's disfranchisers, Black activists, and the courts. In: RISER, Volney R. Defying disfranchisement: Black voting rights activism in the Jim Crow South, 1890-1908. Baton Rouge: Louisiana State University Press, 2010, p. 112-137.
}

\section{CANPHLAC}


tal medida fosse adotada. ${ }^{33}$ Embora tais esforços tenham sido realizados, a nova constituição do estado foi ratificada em novembro daquele ano apresentando elementos que desqualificavam brancos pobres, mas principalmente negros. ${ }^{34}$

Outra instituição significativamente importante para que o afro-americano pudesse conquistar melhorias em sua condição social foi a imprensa negra. Presente desde o período escravista com o lançamento do Freedom 's Journal, em 1827, sua razão de ser estava relacionada à necessidade de expandir a discussão acerca da condição escrava tendo como público alvo, principalmente os cidadãos brancos. Como um advogado pelos direitos dos negros, um dos maiores papeis da imprensa negra foi ser um órgão de protesto (GILLIAM, 1997, p. x).

Durante os seus quase dois séculos de existência, a imprensa negra norteamericana se deparou com constantes mudanças e dificuldades. No contexto pré-guerra civil e durante o período de reconstrução encontrou escasso suporte financeiro, o que colocou em risco sua sobrevivência. No entanto, o agravamento das relações raciais no sul do país e o movimento migratório para as cidades, destacadamente para a região norte, proporcionou uma nova fase ao empreendimento. Tal fator teve a capacidade de modificar a consciência do proletariado negro ao desenvolver o instinto de solidariedade. Esse foi o caminho pelo qual o imigrante negro mal capacitado e hostilizado pelos sindicatos mais antigos utilizou para levar adiante a solidariedade racial. Soma-se a esse aspecto a contribuição que o processo migratório tem para o surgimento de uma classe média negra que possibilitou uma modificação de mercado e resultou em uma maior independência da imprensa em questão. ${ }^{35}$

Dentre as muitas contribuições proporcionadas pela imprensa negra estava a possibilidade de escritores divulgarem os seus trabalhos literários nas páginas de

\footnotetext{
${ }^{33}$ Cf. Letter from Booker T. Washington, principal of Tuskegee Normal and Industrial Institute, to John B. Knox, president of the constitutional convention in Montgomery, Alabama.

${ }^{34}$ Dentre os elementos utilizados para efetivar o processo de segregação no estado estão o pagamento de taxas para os eleitores, a leitura e escrita de qualquer artigo da constituição nacional e que tenham servido ou fossem descendentes de ex-veteranos dos conflitos empreendidos pelo país no século XIX. Este último elemento quase impossível para um afro-americano alcançar. Cf. Constitution of Alabama 1901. http://alisondb.legislature.state.al.us/alison/codeofalabama/constitution/1901/toc.htm.

${ }_{35}$ Para saber mais sobre o processo de desenvolvimento da imprensa afro-americana, ver: WOLSELEY, Roland E. The Black Press: USA. Ames, Iowa: Iowa State University Press, [1971] 1990.
}

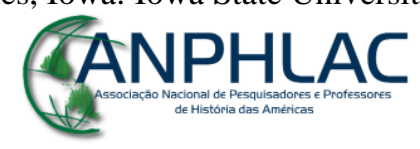

Revista Eletrônica da ANPHLAC, ISSN 1679-1061, № 27, p. 103-143, Ago./, Dez., 2019. http://revista.anphlac.org.br 
periódicos e, na maior parte das vezes, suas produções, ainda que contendo elementos fictícios, tinham a função de expor as contradições da democracia americana. ${ }^{36}$ De acordo com Vogel (2001, p. 2), o relativamente barato papel-jornal e a frequência de publicação da imprensa ampliaram as liberdades dos escritores negros. Além desse fator, contribuíram para tornarem os escritores mais ágeis de forma que pudessem se precipitar aos debates públicos revelando suas visões e opiniões quase que imediatamente.

O caráter militante atribuído aos periódicos negros foi um elemento que intrigou profissionais que não faziam parte daquele ciclo. O jornalista e historiador Patrick $S$. Washburn (2006, p. xvi), destacou uma carência de objetividade em apresentar notícias vinculadas ao contexto negro norte-americano. Para ele, havia uma mistura de declarações objetivas com comentários dos editores, o que se revelou uma combinação poderosa e interessante, altamente divertida e efetiva. $\mathrm{O}$ fato de a imprensa tradicional, ou mainstream press, estar nas mãos de indivíduos brancos que negligenciavam os assuntos relacionados aos negros proporcionou, de acordo com Vogel (2001, p. 3), o desenvolvimento de uma imprensa que por vezes se utilizou de assuntos corriqueiros do cotidiano para fazer uma intermediação sobre como enfrentar a discriminação, assuntos políticos e diversas outras questões. Como exemplos de periódicos que se engajaram na luta contra a segregação e discriminação estão o Boston Guardian, fundado, em 1901, por William Monroe Trotter e George Forbes, o Chicago Defender, fundado por Robert S. Abbott, em 1905 e a The Crisis Magazine: A Record of the Darker Races, em 1910.

Atualmente, podem-se verificar no Brasil estudos que procuram abordar a atuação da imprensa afro-americana em discutir as problemáticas que assolavam a comunidade em face ao racismo e segregacionismo estadunidense. O historiador Flávio Thales Ribeiro Francisco, em dois significativos trabalhos, Fronteiras em Definição (2013) e O Novo Negro na Diáspora (2016), resultantes de seu mestrado e doutorado, respectivamente, discute o uso feito pelo jornal paulistano, dirigido à comunidade negra, $O$ Clarim $d a$

\footnotetext{
${ }^{36}$ Muitos intelectuais e escritores começaram suas carreiras publicando em jornais e revistas. Dentre esses, pode-se citar Charles Chesnutt, Paul Laurence Dunbar e Alain Locke que publicaria, em 1925, o livro The New Negro, demonstrando a revolução cultural desencadeada pelos negros que ficaria conhecida como Harlem Renaissance.
}

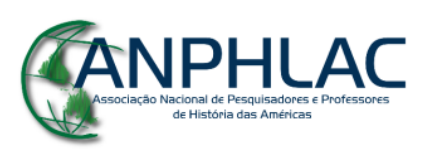

Revista Eletrônica da ANPHLAC, ISSN 1679-1061, № 27, p. 103-143, Ago./, Dez., 2019. http://revista.anphlac.org.br 
Alvorada (1924-1932), das experiências negras internacionais por meio dos periódicos norte-americanos Chicago Defender e Negro World. De acordo com Flávio Francisco (2013, p. 12), os projetos defendidos pelo jornal paulistano foram influenciados não apenas pelo contexto brasileiro, mas também por notícias acerca do racismo e das lutas travadas pelas lideranças negras dos Estados Unidos e do continente africano. Também faz parte de seus estudos as representações que o Chicago Defender procurou discutir e difundir das experiências negras do Brasil e da França, apresentando os dois países como exemplos de democracias raciais e ocasionando debates sobre essa pretensa idealização.

Outro importante trabalho é o da historiadora Luciana da Cruz Brito, já mencionada anteriormente, em Impressões Norte-Americanas sobre Escravidão, Abolição e Relações Raciais no Brasil Escravista. A tese, defendida em 2014, apresenta uma ampla gama de interpretações sobre o relacionamento entre negros e brancos no país. Enquanto abolicionistas afro-americanos viam no Brasil um local onde vigorava o respeito e a boa convivência entre as "raças", outros elementos da sociedade norteamericana, como cientistas e viajantes, enxergavam a miscigenação existente na região como um dos principais determinantes para a degeneração de sua população. $O$ trabalho se utiliza de diversas fontes como relatos de viagens, textos científicos, cartas de imigrantes confederados e jornais da imprensa negra abolicionista.

Embora tenha atravessado décadas intercalando momentos de contestação e prestígio, a imprensa negra não apresenta o mesmo impacto que antes. Dentre os elementos de podem ser citados para o seu declínio, encontra-se a sempre caótica situação econômica com a falta de grandes anunciantes, a necessidade de se evitar atritos significativos com a imprensa dominante e a contratação de jornalistas negros pela imprensa tradicional a partir da efervescência dos anos 1950 e $1960 .{ }^{37}$ No entanto, na visão de Clint C. Wilson II (2014, p. 164), a imprensa negra ainda é viável, embora a tarefa seja descomunal. Basta saber se a imprensa negra pode reunir a determinação e os meios para encontrar os desafios à sua frente.

\footnotetext{
${ }^{37}$ Para saber mais sobre o processo de decadência da imprensa afro-americana, ver: From an incredible high to an incredible low. In: WASHBURN, op. cit., 2006, p. 179-196.
}

\section{GANPHLAC}




\section{Considerações finais}

A questão racial que opôs brancos e negros nos Estados Unidos, destacadamente após a guerra civil, pode ser compreendida como a mais problemática do país. Essa conturbada relação de convivência que se inicia com a chegada da primeira leva de escravos africanos, em 1619, em Jamestown, na Virgínia, deixou consideráveis e profundas cicatrizes perceptíveis até os dias de hoje. Durante todos esses anos, uma mescla de repressão e resistência evidenciou a caótica situação do afro-americano e o seu objetivo de se ser inserido na sociedade estadunidense.

Após o conflito civil entre os estados do norte e do sul, um marco na definição do que seria a nação norte-americana, procedimentos perpetrados pelos antigos senhores de escravos do sul procuraram mostrar aos negros que sem submissão a expectativa de sobrevivência seria praticamente nula. Podem-se atestar procedimentos legais cujo objetivo era limitar os ganhos decorrentes da emancipação. Evitando uma possível competição econômica contra aqueles que há pouco tempo eram suas propriedades, restringiram a aquisição de terras e contaram com aliados políticos para levarem a feito suas pretensões. Com o passar do tempo e utilizando o fator racial, conseguiram levar para o seu lado brancos pobres que estavam quase tão desolados quanto os negros. Embora medidas advogadas por políticos considerados radicais pretendessem garantir igualdade de condições para os recém libertos, aquele fator aliado a problemas econômicos fez com que o interesse pela condição do negro fosse deixado de lado.

No final do século XIX, ideias que sustentavam a divisão dos seres humanos entre aqueles evoluídos e aqueles na base dos grupos sociais eram uma concepção corrente no universo norte-americano. Esse pensamento, aliado a outras temáticas nacionais, contribuiu para separar ainda mais os brancos, alguns defensores da "supremacia branca", e os negros. A política Jim Crow, que se instaurou no sul do país, mas que tinha ramificações pelas demais regiões, revelou um dos capítulos mais vergonhosos da história dos Estados Unidos. Exclusão política e econômica, oportunidades escassas em ascensão

\section{GANPHLAC}


profissional e violência física, por vezes transformada em espetáculo público, eram as demonstrações mais comuns desse pesadelo que durou décadas.

Ainda no final do século XIX, algumas medidas procuraram questionar aquele estado de coisas. Embora o combate à segregação pareça ter vindo na esteira de outras questões que ameaçavam o equilíbrio da sociedade americana, a aproximação entre brancos e negros de tendência progressista se mostrou significativa na revelação de um dos problemas mais duradouros da trajetória do país. Essa união, que algumas vezes apresentou atritos entre os acordantes, foi sustentada com a finalidade de proporcionar um ambiente mais seguro para as duas partes. Procurando agir dentro do sistema, e recebendo críticas por isso, conquistas foram duramente alcançadas, inclusive fora do período aqui trabalhado. ${ }^{38}$

\section{Referências Bibliográficas}

\section{Fontes}

Constitution of Alabama 1901. Disponível em: http://alisondb.legislature.state.al.us/alison/codeofalabama/constitution/1901/toc.htm. Acesso em: 02/04/2018.

Constitution of the State of Louisiana, 1898, Article 197. Disponível em: http://archive.org/details/constitutionsta02louigoog. Acesso em: 02/04/2018.

Letter from Booker T. Washington, principal of Tuskegee Normal and Industrial Institute, to John B. Knox, president of the constitutional convention in Montgomery, Alabama. Disponível em: http://digital.archives.alabama.gov/cdm/ref/collection/voices/id/7070. Acesso em 02/04/2018.

The Daily Inter-Ocean, 4 de agosto de 1894, Vol. XXIII, №. 133, p. 9. Disponível em: https://www.lib.uchicago.edu/ead/pdf/ibwells-0008-010-08.pdf. Acesso em: 02/04/2018.

\footnotetext{
${ }^{38}$ Pode-se citar, por exemplo, que em dezembro de 2018, o Senado dos Estados Unidos aprovou uma lei fazendo do linchamento um crime federal. Depois de mais de um século de esforço, esse ato representa mais uma vitória nas duras batalhas empreendidas pelos afro-americanos para poderem viver mais dignamente em seu país. Cf. https://edition.cnn.com/2018/12/19/politics/senate-antilynching/index.html?fbclid=IwAR3ucDOQUYDbd2OGwNS6FifYoSMJdbAnHAeIkYNPUrC6NktYSrD VzW4NU5U e https://www.booker.senate.gov/?p=press_release\&id=876.
}

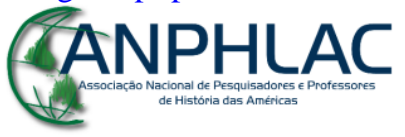


The Sun, 26 de julho de 1894, p. 7. Disponível em: https://chroniclingamerica.loc.gov/lccn/sn83030272/1894-07-26/ed-1/seq-7/. Acesso em 03/04/2018.

The Sun, July 30, 1894, p. 2. Disponível em: https://chroniclingamerica.loc.gov/lccn/sn83030272/1894-07-30/ed-1/seq-1/. Acesso em: 03/04/2018.

WALLING, William English. The Race War in the North. In: The Independent, n. 65, Sept.3,1908.Disponívelem:http://www.eiu.edu/past tracker/AfricanAmerican_Independ ent65_3Sept1908_RaceWarInTheNorth.pdf. Acesso em: 03/04/2018.

Edições da revista The Crisis disponíveis em: http://modjourn.org/render.php?view=mjp_object\&id=crisiscollection. Acesso em 09/10/2012.

\section{Sites}

CNN Politics: https://edition.cnn.com/2018/12/19/politics/senate-anti-

lynching/index.html?fbclid=IwAR3ucDOQUYDbd2OGwNS6FifYoSMJdbAnHAeIkYNPUrC6 NktYSrDVzW4NU5U.

Cory Booker (United States Senator for New Jersey):

https://www.booker.senate.gov/?p=press release\&id=876.

\section{Bibliografia}

ANDERSON, William G. Progressivism: An Historiographical Essay. In: The History Teacher, v. 6, n. 3, May 1973, p. 427-452. Disponível em: http://www.jstor.org/stable/492218. Acesso em: 06 dez. 2012.

ARNDT, Murray Dennis. The Crisis Years of W. E. B. Du Bois, 1910-1934. Dissertation (Language and Literature, modern), Duke University, Ph. D, 1971.

BREXEL, Bernadette. The Populist Party: a voice for the farmers in an industrial society. New York: Rosen Publishing Group, 2004.

BRITO, Luciana da Cruz. Impressões Norte-Americanas sobre Escravidão, Abolição e Relações Raciais no Brasil Escravista. Tese de Doutorado em História Social, FFLCHUSP, São Paulo, 2014.

\section{GANPHLAC}


BRUNDAGE, W. Fitzhugh. Lynching in the New South: Georgia and Virginia, 18801930. Urbana: University of Illinois Press, 1993.

BURTON, Vernon. Sharecropping. In: ZUCZEK, Richard (Ed.). Encyclopedia of the Reconstruction era. Westport, Connecticut; London: Greenwood Press, v. 2, 2006, p. 563-567.

CARSON, Mina. Settlement folk: social thought and the American settlement movement, 1885-1930. Chicago: University of Chicago Press, 1990.

CIMBALA, Paul A. The Freedmen's Bureau: reconstructing the American South after the Civil War. Malabar, FL: Krieger Publishing, 2005.

CRIPPS, Thomas. Slow fade to black: the Negro in American film, 1900-1942. Oxford; New York: Oxford University Press, 1993.

CUTHBERT-KERR, Simon T. Black Codes. In: BROWN, Nikki L. M.;

STENTIFORD, Barry M. (Eds.). The Jim Crow Encyclopedia. Westport, Connecticut; London: Greenwood Press, v. 1, 2008, p. 78-85.

DAWSON III, Joseph G. Military Reconstruction Acts (1867-1868). In: ZUCZEK, Richard (Ed.). Encyclopedia of the Reconstruction era. Westport, Connecticut; London: Greenwood Press, v.2, 2006, p. 406-410.

DEHLER, Gregory J. Radical Republicans. In: ALEXANDER, Leslie M.; RUCKER, Walter C. (Eds.). Encyclopedia of African-American history. Santa Barbara, California: ABC-CLIO, 2010, p. 974-976.

DINER, Steven J. A Very Different Age: Americans of the Progressive Era. New York: Hill and Wang, 1998.

DU BOIS, W. E. B. Black reconstruction in America, 1860-1880. New York: Touchstone, 1995.

The Autobiography of W. E. B. Du Bois: A Soliloquy on Viewing My Life from the Last Decade of Its First Century. New York: International Publishers, [1968] 1988.

. The souls of Black folk. Oxford; New York: Oxford University Press, [1903] 2007. (Oxford World's Classics)

FAIRCLOUGH, Adam. Better day coming: Blacks and equality, 1890-2000. New York: Penguin Books, 2002.

\section{GANPHLAC}


FONER, Eric. Politics and ideology in the age of the Civil War. New York: Oxford University Press, 1980.

York: Harper \& Row, 1988a.

Reconstruction: America's Unfinished Revolution, 1863-1877. New

. Nada além da liberdade: a emancipação e seu legado. Tradução de Luiz

Paulo Rouanet. Rio de Janeiro: Paz e Terra, 1988b.

FRANCISCO, Flávio Thales Ribeiro. Fronteiras em definição: identidades negras e imagens dos Estados Unidos e da África no jornal O Clarim da Alvorada (1924-1932). São Paulo: Alameda, 2013.

O novo negro na diáspora: modernidade afro-americana e as representações sobre o Brasil e a França no jornal Chicago Defender (1916-1940). São Paulo: Intermeios; Fapesp, 2016.

GILLIAM, Doroth. Foreword. In: PRIDE, Armistead S.; WILSON II, Clint C. A History of the Black Press. Washington, D. C.: Howard University Press, 1997, p. ix-xi.

GOULD, Stephen Jay. The mismeasure of man. New York: W. W. Norton \& Company, 1996.

HAWKINS, Mike. Social Darwinism in European and American thought, 1860-1945: nature as a model and nature as threat. Cambridge: Cambridge University Press, 1997.

JOHNSON, Sherita L. Disenfranchisement. In: BROWN, Nikki L. M.; STENTIFORD, Barry M. (Eds.). The Jim Crow Encyclopedia. Westport, Connecticut; London: Greenwood Press, v. 1, 2008, p. 229-233.

KEITH, LeeAnna. The Colfax massacre: the untold story of Black Power, White terror, and the death of Reconstruction. New York: Oxford University Press, 2008.

KELLOGG, Charles Flint. NAACP: A History of the National Association for the Advancement of Colored People. (1909-1920). Baltimore; London: The Johns Hopkins University Press, v.1, 1973.

KNIGHT, Gladys L. Icons of African American protest: trailblazing activists of the civil rights movement. Westport, Connecticut; London: Greenwood Press, v.2, 2009.

LEARS, Jackson. Rebirth of a Nation: The making of modern America, 1877-1920. HarperCollins e-books, 2009.

LOGAN, Rayford W. The Negro in American Life and Thought: The Nadir. New York: Dial Press, 1954.

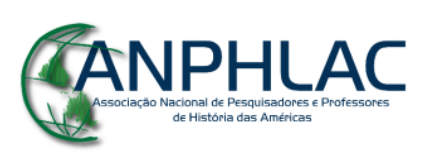

Revista Eletrônica da ANPHLAC, ISSN 1679-1061, № 27, p. 103-143, Ago./, Dez., 2019.

http://revista.anphlac.org.br 
The Betrayal of the Negro: From Rutherford B. Hayes to Woodrow Wilson. New York: Da Capo Press [1965] 1997.

LEONARD, Thomas C. Illiberal reformers: race, eugenics and American economics in the Progressive Era. Princeton; Oxford: Princeton University Press, 2016.

LEWIS, David Levering. W. E. B. Du Bois: biography of a race, 1868-1919. New York: Owl Books, 1993.

MALONEY, Thomas N. African Americans in the Twentieth Century. In: E.H.Net Encyclopedia. edited by Robert Whaples. January 14, 2002. Disponível em: https://eh.net/encyclopedia/african-americans-in-the-twentieth-century/. Acesso em: 26 jan. 2019.

McCASLIN, Nancy A. Black Codes In: ALEXANDER, Leslie M.; RUCKER, Walter C. (Eds.). Encyclopedia of African American History. Santa Barbara, California: ABCCLIO, 2010, p. 651-652.

McGERR, Michael. A Fierce Discontent: the rise and fall of the Progressive movement in America, 1870-1920. New York: Oxford University Press, 2005.

MEIER, August; BRACEY Jr., John H. The NAACP as a Reform Movement, 1909-1965: "To Reach the Conscience of America". In: The Journal of Southern History, v. 59, n. 1, Feb. 1993, p. 3-30. Disponível em: http://www.jstor.org/stable/2210346. Acesso em: 04 mar. 2012.

MYRDAL, Gunnar. An American Dilemma: The Negro Problem and Modern Democracy. New York: Harper \& Brothers Publishers, 1944.

NASCIMENTO, Carlos Alexandre da Silva. Representando o "Novo" Negro NorteAmericano: W. E. B. Du Bois e a Revista The Crisis, 1910-1920. Dissertação de Mestrado em História Social, FFLCH-USP, São Paulo, 2015.

NICHOLS, Christopher McKnight; UNGER, Nancy C. (Eds.). A companion to the Gilded Age and Progressive Era. Chichester, West Sussex, UK: Wiley Blackwell, 2017.

PACKARD, Jerrold M. American Nightmare: the history of Jim Crow. New York: St. Martin's Griffin, 2011.

PIOTT, Steven L. Daily life in the progressive era. Santa Barbara: Greenwood, 2011.

RISER, Volney R. Defying disfranchisement: Black voting rights activism in the Jim Crow South, 1890-1908. Baton Rouge: Louisiana State University Press, 2010.

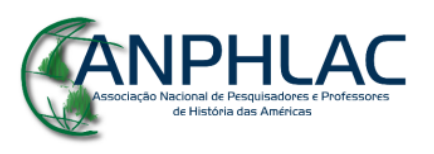

Revista Eletrônica da ANPHLAC, ISSN 1679-1061, № 27, p. 103-143, Ago./, Dez., 2019.

http://revista.anphlac.org.br 
RODRIGUEZ, Michael S. Civil Rights Act of 1964. In: ALEXANDER, Leslie M.;

RUCKER, Walter C. (Eds.). Encyclopedia of African American History. Santa Barbara, California: ABC-CLIO, 2010, p. 701-702.

RODGERS, Daniel T. In Search of Progressivism. In: Reviews of American History, v. 10, n. 4, Dec. 1982, p. 113-132. Disponível em: http://www.jstor.org/stable/2701822. Acesso em: 15 fev. 2013.

ROSENBERG, Rosalind. Beyond separate spheres: intellectual roots of modern feminism. New Haven, CT: Yale University Press, 1982.

SINGER, Peter. A Darwinian Left: politics, evolution and cooperation. New Haven: Yale University Press, [1999] 2000.

SMITH, John David. Black Codes. In: ZUCZEK, Richard (Ed.). Encyclopedia of the Reconstruction era. Westport, Connecticut; London: Greenwood Press, v. 1 2006, p. $72-$ 74. (Greenwood milestones in African American history).

SOUTHERN, David W. The progressive era and race: reaction and reform, 1900-1917. Wheeling, Ill.: Harlan Davidson, Inc., 2005.

STANTON, Mary. Sharecropping. In: BROWN, Nikki L. M.; STENTIFORD, Barry M. (Eds.). The Jim Crow Encyclopedia. Westport, Connecticut; London: Greenwood Press, v.2, 2008, p. 725-730.

STEPHENS, Judith L. Racial Violence and Representations: Performance Strategies in Lynching Dramas of 1920s. In: African American Review, v. 33, n.4, winter 1999, p. 655671. Disponível em: http://www.jstor.org/stable/2901345. Acesso em: 19 mai. 2012.

STROMQUIST, Shelton. Reinventing "The People": the progressive movement, the class problem, and the origins of modern liberalism. Urbana: University of Illinois Press, 2006.

SUGRUE, Thomas. Sweet Land of Liberty: the forgotten struggle for civil rights in the North. New York: Ramdom House Trade Paperbacks, 2008.

TREFOUSSSE, Hans L. Amnesty Proclamations. In: ZUCZEK, Richard (Ed.). Encyclopedia of the Reconstruction era. Westport, Connecticut; London: Greenwood Press, v.1, 2006, p. 43-47. (Greenwood milestones in African American history)

TRODD, Zoe. Voting Rights Act of 1965. In: ALEXANDER, Leslie M.; RUCKER, Walter C. (Eds.). Encyclopedia of African American History. Santa Barbara, California: ABC-CLIO, 2010, p. 1081-1083.

\section{GANPHLAC}


TUTTLE, Jr., William M. Race riot: Chicago in the Red Summer of 1919. Urbana; Chicago: University of Illinois Press, 1996.

UPCHURCH, T. Adams. Historical dictionary of the Gilded Age. Lanham, Maryland: Scarecrow Press, Inc., 2009.

VOGEL, Todd (Ed.). The black press: new literary and historical essays. New Brunswick, NJ; London: Rutgers University Press, 2001.

WALTERS, Ronald W. Freedom Is Not Enough: Black Voters, Black Candidates, and American Presidential Politics. Lanham, MD: Rowman and Littlefield, 2007.

WANG, Xi. Disfranchisement. In: ZUCZEK, Richard (Ed.). Encyclopedia of the Reconstruction era. Westport, Connecticut; London: Greenwood Press, v.1, 2006, p. 200206.

WEELER, Samuel Paul. Civil Rights Act of 1866. In: ALEXANDER, Leslie M.;

RUCKER, Walter C. (Eds.), Encyclopedia of African American History. Santa Barbara, California: ABC-CLIO, 2010, p. 698-699.

WASHBURN, Patrick S. The African American newspaper: voice of freedom. Evanston, Illinois: Northwestern University Press, 2006.

WELLS, Ida B. Crusade for justice: the autobiography of Ida B. Wells. Alfreda M. Duster (ed.). Chicago; London: The University of Chicago Press, 1970. (Negro American Biographies and Autobiographies).

WILSON II, Clint C. Whither the Black Press?: glorious past, uncertain future. [s.1]: Xlibris LLC, 2014.

WOLSELEY, Roland E. The Black Press: USA. Ames, Iowa: Iowa State University Press, [1971] 1990.

WOODLEY, Jenny. Art for equality: the NAACP's cultural campaign for civil rights. Lexington, Kentucky: University Press of Kentucky, 2014.

WOODWARD, C. Vann. The Strange Career of Jim Crow. Oxford; New York: Oxford University Press [1955] 2002.

\section{GANPHLAC}

